Article

\title{
Environmental Impacts on Zooplankton Functional Diversity in Brackish Semi-Enclosed Gulf
}

\author{
Astra Labuce *(D), Anda Ikauniece $\left(\mathbb{D}\right.$, Iveta Jurgensone $\mathbb{D}^{\mathrm{D}}$ and Juris Aigars $(\mathbb{D}$ \\ Latvian Institute of Aquatic Ecology, Agency of Daugavpils University, 4 Voleru Str., LV-1007 Riga, Latvia; \\ anda.ikauniece@lhei.lv (A.I.); iveta.jurgensone@lhei.lv (I.J.); juris.aigars@lhei.lv (J.A.) \\ * Correspondence: astra.labuce@lhei.lv
}

Citation: Labuce, A.; Ikauniece, A.; Jurgensone, I.; Aigars, J. Environmental Impacts on Zooplankton Functional Diversity in Brackish Semi-Enclosed Gulf. Water 2021, 13, 1881. https:// doi.org/10.3390/w13141881

Academic Editor: Marina Marcella Manca

Received: 9 June 2021

Accepted: 2 July 2021

Published: 7 July 2021

Publisher's Note: MDPI stays neutral with regard to jurisdictional claims in published maps and institutional affiliations.

Copyright: (c) 2021 by the authors. Licensee MDPI, Basel, Switzerland. This article is an open access article distributed under the terms and conditions of the Creative Commons Attribution (CC BY) license (https:// creativecommons.org/licenses/by/ $4.0 /)$.
Abstract: Zooplankton as an essential component in the pelagic food web are directly linked to pelagic ecosystem functioning. Therefore, comprehension of zooplankton functional diversity (FD) and its responses to environmental changes is crucial for ecosystem-based view. To identify FD responses to environmental drivers, we analysed 25 years of summer data on the brackish mesozooplankton community (including rotifers, cladocerans, copepods, and meroplankton) from the eutrophied, shallow Gulf of Riga (Baltic Sea). We established that within the Gulf of Riga, open waters are notably different from coastal regions based on the dynamics of hydrological conditions (temperature, salinity), cyanobacterial dominance, abundance of mesozooplankton functional groups, and mesozooplankton FD indices. Competition over resources in combination with hydrodynamic features and predation by adult herring were seemingly the central structuring mechanism behind the dynamics of FD metrics (richness, evenness, divergence, and dispersion) within coastal mesozooplankton communities. Whereas predation by young herring was an important driver only for the mesozooplankton communities in the open waters. Cyanobacterial dominance, used as a proxy for food quality and availability, had no effect on summer mesozooplankton FD metrics.

Keywords: traits; zooplankton; Baltic Sea; Gulf of Riga; functional groups; diversity

\section{Introduction}

Organism survival is dependent on morphological and behavioural characteristics (traits) and associated responses to abiotic filtering and biotic interactions (predation, competition) [1,2]. Therefore, comprehension of links between trait occurrences and environmental changes is of extreme importance for ecosystem assessment and management. Functional trait approach can provide ecologically more profound information on underlying mechanisms than taxonomy-based analysis [3,4]. Functional diversity (FD) metrics consider functional traits of organisms and thus describe ecological roles and strategies of the occurring species and also characterise community assembly [5,6], ecosystem processes $[7,8]$, and resilience $[9,10]$.

Zooplankton are an essential component in the pelagic food web, linking primary production to higher trophic levels, thereby playing a key role in the functioning of aquatic ecosystems [11,12]. FD of zooplankton communities has been addressed in studies from different types of waterbodies worldwide [13], including the brackish Baltic Sea [14-17]. Due to the brackish environment where marine and limnic species meet their physiological limits, zooplankton of the Baltic Sea are characterised by relatively low species richness [18] and also low functional diversity [19]. However, FD of the Baltic zooplankton changes seasonally and along gradients of temperature, salinity, and depth [14,15].

The Gulf of Riga, a highly eutrophic subbasin of the Baltic Sea [20], has a strong impact from riverine discharge [21], strengthening the environmental variability. Thus, zooplankton community composition and assembly in the Gulf of Riga is strongly driven by abiotic factors [22-25]. Hydrological conditions and climate variability are also recognised 
as the main drivers shaping zooplankton FD in the area [15,17], albeit, the effects of biotic interactions on zooplankton FD are left underexplored.

Pecuchet et al. [17] described long-term, ecosystem-wide functional changes in three Baltic Sea subbasins, including the Gulf of Riga, and aside from abiotic factors and zooplankton, they also considered phytoplankton, zoobenthos, and fishery-related parameters. The study revealed strong causal links between multi-trophic community weighted mean, salinity, fisheries, and cod abundances, and expressed the need for further analysis of trophic interactions to assess the results explicitly. However, the study was limited to copepods, thus the results cannot be extrapolated to the whole zooplankton community. Indeed, copepods are the main food source for herring Clupea harengus [26], the main commercial pelagic fish of the region. However, rotifers and cladocerans significantly affect primary producers [27] and serve as a linkage to the microbial food web [28,29]. They provide substantial support for ecosystem production and functioning, especially in shallow, eutrophied, and coastal regions [30] such as the Gulf of Riga [31]. Hence, analysis of FD dynamics for the whole zooplankton community, rather than copepods alone, may provide additional information about the underlying processes shaping community structure.

Our study aims to identify the dynamics of mesozooplankton FD indices and their responses to abiotic and biotic drivers of summer communities (including rotifers, cladocerans, copepods, and meroplankton) in coastal and open water habitats of the Gulf of Riga. We hypothesise that FD of summer zooplankton is mainly shaped by biotic interactions due to (i) pronounced activity within and from the microbial loop [31], e.g., high cyanobacterial biomass [32,33] and (ii) intense predation pressure from herring [34,35]. Using the Gulf of Riga as a case study area, we seek answers to the questions: What are the potential structuring mechanisms of mesozooplankton FD in eutrophied shallow brackish waters and how do they change between coastal and open water habitats?

\section{Materials and Methods}

\subsection{Study Area and Sampling}

The Gulf of Riga is a semi-isolated basin with a north-westward salinity gradient. Salinity ranges between 0.5-2.0 PSU in its southern area, where the largest freshwater discharge occurs [21], to 7.0 PSU in northeast regions, but generally varies from 5.0 to 6.5 PSU [36]. The Gulf of Riga is located in the temperate zone, therefore, the changes in the ecosystem follow a typical temperate seasonal cycle with a productive period from March/April to October. Summer is characterised by the highest sea surface temperature, strongest stratification [37], and increased values of phytoplankton, zooplankton biomass, and diversity $[15,38]$.

We analysed Latvian National marine monitoring data from four open water and nine coastal sites (Figure 1). The open water sites ( $>40 \mathrm{~m}$ deep) had a stratified water column during the summer, with thermocline at approximately $15 \mathrm{~m}$ in depth. Coastal sites (depth $<15 \mathrm{~m}$ ) were divided into three coastal areas based on their geographical location (western, southern, and eastern) and according to freshwater impacts (north-westward salinity gradient). Data collected in summer (25-38 week of the year) during the period from 1993 to 2017 were used. The data frequency is shown in Table 1.

Mesozooplankton samples were collected from the whole water column following recommendations by the Baltic Marine Environment Protection Commission (HELCOM) [39] (and previous versions). The only deviation from the recommended methodology was the omission of a flow meter on the WP2 net (mesh size: $100 \mu \mathrm{m}$ ). Therefore, the sampled volume was calculated using the formula for the volume of a cylinder (diameter: $0.57 \mathrm{~m}$ ), taking into account the depth of the sampled site and the angle of a winch wire during sampling. Mesozooplankton samples were preserved in $4 \%$ buffered formaldehyde in seawater. Zooplankton taxa (Table 2) were identified to the lowest possible taxonomic level using atlases [40,41] and ICES leaflets [42]. The majority of holoplanktonic taxa were identified to the species level, except for Cyclopoida copepods which were identified 
to order. Meroplanktonic larvae were identified to class (e.g., Polychaeta, Bivalvia) and only Amphibalanus larvae were identified to genus level.

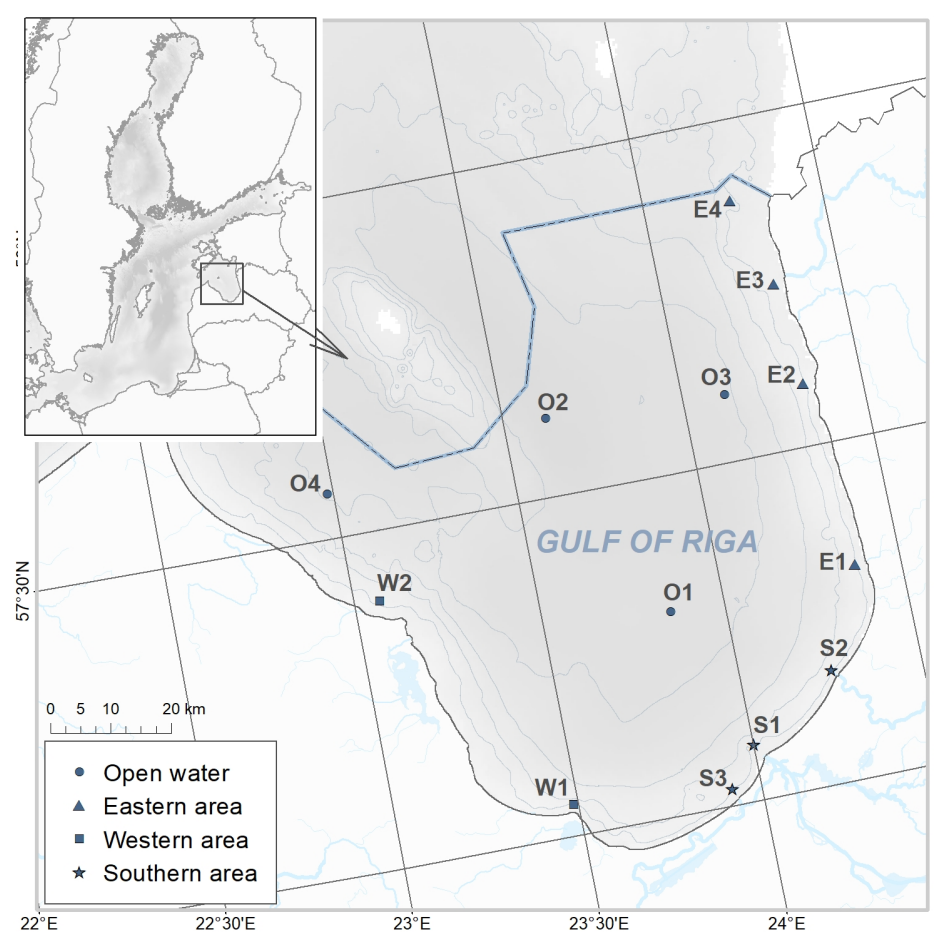

Figure 1. Position of sampling sites in the study area, the Gulf of Riga. The location of the Gulf of Riga in the Baltic Sea is shown in the small panel figure.

Phytoplankton samples were collected from surface waters $(0-10 \mathrm{~m})$ using a plastic hose and processed and analysed following HELCOM recommendations [39] (and previous versions). Herring population data were obtained from an annual report [43] by the Baltic Fisheries Assessment Working Group (WGBFAS) of the International Council for the Exploration of the Sea (ICES). Sea surface temperature (SST) and sea surface salinity (SSS) were measured using a CTD water probe, calculated to obtain the weighted average of the top 10-m layer.

Table 1. Data frequency at each site (see location in Figure 1) over the studied season (25-38 weeks of the year) per year.

\begin{tabular}{cccccccccccccc}
\hline Year & O1 & O2 & O3 & O4 & E4 & E3 & E2 & E1 & S2 & S1 & S3 & W1 & W2 \\
\hline 1993 & 1 & 0 & 0 & 1 & 0 & 1 & 1 & 0 & 1 & 1 & 1 & 0 & 0 \\
1994 & 7 & 1 & 0 & 1 & 0 & 0 & 1 & 1 & 3 & 3 & 3 & 3 & 0 \\
1995 & 4 & 1 & 1 & 1 & 0 & 1 & 1 & 2 & 2 & 2 & 2 & 2 & 0 \\
1996 & 1 & 2 & 0 & 0 & 0 & 0 & 0 & 1 & 1 & 1 & 1 & 1 & 0 \\
1997 & 0 & 1 & 1 & 1 & 0 & 0 & 0 & 2 & 3 & 3 & 3 & 2 & 0 \\
1998 & 4 & 1 & 0 & 0 & 0 & 0 & 0 & 3 & 3 & 5 & 2 & 3 & 0 \\
1999 & 6 & 2 & 0 & 0 & 0 & 1 & 0 & 3 & 1 & 6 & 3 & 3 & 0 \\
2000 & 2 & 3 & 1 & 1 & 1 & 0 & 0 & 3 & 3 & 4 & 3 & 3 & 0 \\
2001 & 6 & 2 & 1 & 1 & 1 & 0 & 0 & 3 & 3 & 6 & 3 & 3 & 0 \\
2002 & 6 & 3 & 1 & 1 & 1 & 0 & 0 & 3 & 3 & 7 & 2 & 3 & 1 \\
2003 & 6 & 3 & 1 & 1 & 1 & 0 & 0 & 3 & 2 & 7 & 2 & 3 & 1 \\
2004 & 3 & 1 & 1 & 1 & 1 & 0 & 0 & 3 & 1 & 4 & 2 & 2 & 0 \\
2005 & 1 & 1 & 1 & 1 & 0 & 0 & 0 & 1 & 1 & 1 & 1 & 1 & 0 \\
2006 & 2 & 0 & 1 & 1 & 1 & 0 & 0 & 2 & 1 & 2 & 1 & 2 & 0 \\
2007 & 3 & 1 & 1 & 1 & 1 & 0 & 0 & 3 & 1 & 4 & 2 & 2 & 0 \\
2008 & 3 & 1 & 1 & 1 & 1 & 0 & 0 & 3 & 1 & 4 & 2 & 2 & 0 \\
2009 & 3 & 1 & 1 & 1 & 1 & 0 & 0 & 3 & 1 & 4 & 2 & 2 & 0 \\
\hline
\end{tabular}


Table 1. Cont.

\begin{tabular}{cccccccccccccc}
\hline Year & O1 & O2 & O3 & O4 & E4 & E3 & E2 & E1 & S2 & S1 & S3 & W1 & W2 \\
\hline 2010 & 2 & 2 & 0 & 2 & 0 & 0 & 0 & 1 & 1 & 1 & 1 & 1 & 1 \\
2011 & 2 & 0 & 0 & 0 & 0 & 0 & 0 & 0 & 0 & 0 & 0 & 0 & 0 \\
2012 & 3 & 2 & 0 & 0 & 0 & 0 & 0 & 0 & 0 & 0 & 0 & 0 & 0 \\
2013 & 1 & 1 & 1 & 0 & 0 & 0 & 0 & 1 & 1 & 1 & 0 & 1 & 0 \\
2014 & 1 & 1 & 1 & 1 & 1 & 0 & 0 & 1 & 1 & 1 & 1 & 1 & 0 \\
2015 & 1 & 1 & 1 & 1 & 1 & 0 & 0 & 1 & 1 & 1 & 1 & 1 & 1 \\
2016 & 1 & 1 & 1 & 1 & 1 & 0 & 0 & 1 & 1 & 1 & 1 & 1 & 1 \\
2017 & 1 & 1 & 1 & 1 & 1 & 0 & 0 & 1 & 1 & 1 & 5 & 1 & 4 \\
\hline
\end{tabular}

Table 2. Mesozooplankton species observed during the study period in the Gulf of Riga. Taxa affiliation as in the WORMS database.

\begin{tabular}{ccc}
\hline Taxonomic Affiliation & Abbreviation & Group \\
\hline Bosmina (Eubosmina) coregoni & Bos & Cladocera \\
Cercopagis (Cercopagis) pengoi & Cerc & Cladocera \\
Evadne normanni & Evad & Cladocera \\
Pleopis polyphemoides & Pleo & Cladocera \\
Acartia spp. & AcSpp & Copepoda \\
Acartia longiremis & AcLon & Copepoda \\
Cyclopoida & Cycl & Copepoda \\
Eurytemora affinis affinis & Eury & Copepoda \\
Limnocalanus macrurus & Limn & Copepoda \\
Temora longicornis & Tem & Copepoda \\
Calanoida Copepoda nauplii & CalN & Copepoda \\
Cyclopoida Copepoda nauplii & CylN & Copepoda \\
Keratella cochlearis & KerCoch & Rotifera \\
Keratella quadrata & KerQua & Rotifera \\
Keratella cruciformis & KerCruc & Rotifera \\
Synchaeta monopus (but see [44]) & SySpp & Rotifera \\
Synchaeta baltica & SyBal & Rotifera \\
Amphibalanus larvae & Amph & Meroplankton \\
Bivalvia larvae & Biv & Meroplankton \\
Gastropoda larvae & Gast & Meroplankton \\
Polychaeta larvae & Poly & Meroplankton \\
\hline
\end{tabular}

\subsection{Mesozooplankton Traits and Functional Groups}

We described FD of summer zooplankton community using functional traits on body size, feeding behaviour, and trophic role (Table 3) - a combination that is useful for determining "who eats whom" and identifying potential biotic interactions [45]. Feeding mode was defined based on classification described by Kiørboe [46], except for 'raptorial' mode that was added and combined with the $C$ category, as it resembles 'cruising' feeding mode. 'Raptorial' feeding mode was used to describe the feeding of predatory cladocerans (Onychopoda). 'Mixed' feeding mode was assigned to organisms that show the ability to switch between two or more feeding modes. Mean individual length and prey size values were categorised. Taxa-wise values are shown in Table 3.

We applied hierarchical agglomerative clustering to define functional groups of zooplankton communities. Gower's dissimilarity matrix was used as an input for clustering. The agglomeration method and optimal cluster number were identified by evaluating cluster validation statistics (R software v3.6.1 [47]; package 'fpc' v.2.2-5 [48]). Ultimately, the 'complete linkage' method and five clusters were chosen (Table 3). The first group (G1) compounded small-sized herbivorous filter-feeders. The second group (G2) consisted of small-sized carnivorous copepods from the order Cyclopoida but were not used for subsequent analyses due to limited occurance data. The third (G3) and fourth (G4) group were comprised of omnivorous taxa. Large omnivorous taxa feeding on larger prey were grouped in G3, whereas small omnivorous taxa feeding on small prey were assigned to G4. 
The fifth group (G5) was formed of taxa that are selectively preyed upon by adult herring in the Gulf of Riga [26] regardless of the dietary and morphologic differences. We identified functional groups to comprehensively evaluate ecological features affecting the dynamics of zooplankton FD. The abundances of functional groups were treated as environmental drivers, whereas zooplankton FD indices were calculated taxa-wise, ignoring the division in groups (see Section 2.3).

Table 3. Mesozooplankton functional traits and their values. Abbreviations of taxa (Abbr) as in Table 2. All traits are categorical. FM (feeding mode): A, ambush; F, feeding current; C, cruising/raptorial; M, mixed feeding; ML (mean length): $1, \leq 0.40 \mathrm{~mm} ; 2,0.41-0.80 \mathrm{~mm} ; 3,0.81-1.20 \mathrm{~mm}$; 4, 1.21-1.60 mm; 5, 1.61-2.00 mm; PS (prey size): $1, \leq 0.010 \mathrm{~mm} ; 2,0.011-0.050 \mathrm{~mm} ; 3,>0.050 \mathrm{~mm}$; TG (trophic group): $\mathrm{H}$, herbivore; $\mathrm{C}$, carnivore; $\mathrm{O}$, omnivore; $\mathrm{HS}$ (selectively predated by herring; categories defined based on a study by Livdāne [26]): 0 , not selectively predated; 1 , moderately selected; 2, highly selected. References in square brackets. The dendrogram is based on Gower's dissimilarity using 'complete linkage' agglomeration.

\begin{tabular}{|c|c|c|c|c|c|c|c|}
\hline $\begin{array}{l}\text { Func. } \\
\text { Group }\end{array}$ & Abbr & FM & ML & PS & TG & HS & Dendrogram \\
\hline \multirow{7}{*}{ G1 } & KerCoch & $F[49]$ & $1[50]$ & 1 [49] & $H$ [49] & 0 & \\
\hline & KerQua & $F[49]$ & 1 [50] & 1 [49] & $H[49]$ & 0 & \\
\hline & KerCruc & $F[49]$ & $1[50]$ & 1 [49] & $H[49]$ & 0 & \\
\hline & Amph & $F[51]$ & 1 [41] & 1 [51] & $H[51]$ & 0 & \\
\hline & Poly & $F[49]$ & 1 [52] & 1 [52] & $H[52]$ & 0 & \\
\hline & Biv & $F[53]$ & 1 [54] & 1 [53] & $H[54]$ & 0 & \\
\hline & Bos & $F[55]$ & 1 [41] & 1 [56] & $H$ [55] & 1 & \\
\hline G2 & Cycl & $A[57]$ & 2 [41] & 2 [56] & $C[58]$ & 0 & \\
\hline \multirow{5}{*}{ G3 } & Pleo & $M[59,60]$ & 3 [41] & $2[59,60]$ & $C[59,60]$ & 1 & \\
\hline & Evad & $M[59,60]$ & 4 [41] & $2[59,60]$ & $O[59,60]$ & 1 & \\
\hline & AcSpp & $M[57]$ & 3 [57] & $2[56]$ & $O[61]$ & 0 & \\
\hline & AcLon & $M$ [57] & 3 [57] & $2[56]$ & $O[61]$ & 0 & \\
\hline & Tem & $F[57]$ & 4 [57] & $2[56]$ & $O[62]$ & 0 & \\
\hline \multirow{4}{*}{ G4 } & SySpp & C [49] & 1 [63] & 1 [49] & $O$ [49] & 0 & \\
\hline & SyBal & C [49] & 1 [63] & 1 [49] & $O$ [49] & 0 & \\
\hline & CalN & $C[64]$ & 1 [64] & $1[56]$ & $O[65]$ & 0 & \\
\hline & CycN & C [64] & 1 [64] & 1 [56] & $O[58]$ & 0 & \\
\hline \multirow{3}{*}{ G5 } & Limn & $C[66]$ & 5 [57] & $3[56]$ & $C[66]$ & 2 & \\
\hline & Cerc & $C$ [67] & 5 [68] & $3[56]$ & $C$ [67] & 1 & \\
\hline & Eury & C [57] & 4 [57] & $2[56]$ & $O$ [69] & 2 & \\
\hline
\end{tabular}

\subsection{Functional Diversity Indices}

Four FD indices (FRic, FEve, FDis, and FDiv) were calculated by the means of the $d b F D$ function from the 'FD' package $[70,71]$ using R v3.6.1. Gower's dissimilarity between species based on traits (Table 3) were calculated and used as an input value. All traits were weighted equally during $d b F D$ processing, whereas indices were weighted by the relative abundances (ind $/ \mathrm{m}^{3}$ ) of species.

Functional richness (FRic) represents the amount of niche space filled by taxa in the community. Functional evenness (FEve) describes the evenness of abundance distribution 
within the filled niche space. Functional divergence (FDiv) quantifies how the trait values are spread along the range of a trait space by characterising the degree to which abundance distribution in niche space maximises divergence in functional traits [72]. FDiv increases if the most abundant taxa occur towards extreme points of the filled niche space. Functional dispersion (FDis) is a multidimensional index based on multi-trait dispersion [70] and is mathematically similar to the Rao quadratic entropy [73]. The FDis metric is the average distance of individual taxa to the abundance-weighed centroid of the community trait space [5].

Indices FRic, FDis, and FDiv were adjusted with a matrix-swap null models as noted by Mason et al. [5] and Swenson [74]. Community matrix randomisation with the independent swap algorithm (1000 permutations) was performed using randomizeMatrix from the 'picante' package [75]. In further analysis, only standardised effect sizes of FRic, FDis, and FDiv indices were used, yielding SESFRic, SESFDis, and SESFDiv. FEve were not adjusted (following Mason et al. [5]) and used as calculated by the $d b F D$.

\subsection{Data Analysis}

We analysed the dynamics of mesozooplankton FD in relation to several environmental parameters: SST and SSS, the ratio of cyanobacterial biomass to other phytoplankton biomass (cyano:other ratio), total herring biomass (her-totBio), spawning stock biomass (her-totSPbio; 2+ year old herring), herring recruitment (her-Rec; one-year old herring), and abundances of mesozooplankton functional groups as defined in Table 3. The data for all environmental variables (except for herring parameters) are compiled in the Supplementary Material.

Multiple Factor Analysis (MFA) was used to identify spatial environmental gradients of the Gulf of Riga, to define differences in the study areas (open waters, eastern coastal area, western coastal area, and southern coastal area) and to describe co-varying environmental parameters. MFA input data were FD indices, SST, SSS, cyano:other ratio, and abundances of mesozooplankton functional groups, conducted using the 'FactoMineR' package [76]. Coastal sites were pooled accordingly to their location (Figure 1) and freshwater impacts [21]. The mean value for each coastal area was used in MFA as the sites were surveyed irregularly, whereas open waters were represented site-wise. Each year was described by one value from each of the coastal areas (eastern, western, and southern; Figure 1) and four values from open waters (sites O1-O4; Figure 1). The abundance data of mesozooplankton functional groups and cyano:other ratio were normalised (boxcox transformation) prior to analysis using the 'bestNormalize' package [77].

To evaluate responses of mesozooplankton FD to variations in hydrological parameters (SST, SSS), cyanobacterial dominance (cyano:other ratio), dynamics of zooplankton functional groups, and predation pressure (her-totSPbio, her-totBio, and her-Rec), we used Generalised Additive Modelling (GAM) with the smoothing spline function constrained to five degrees of freedom. To assess the predictive performance of the relationship, a non-random 9:1 train-test split was conducted. The response was assessed on data from 1993-2014, whereas the test data were from 2015-2017. Mean values per year, per region (open waters, coastal area) were used during the analysis due to the low spatial resolution of herring data that describe the Gulf of Riga population as a whole. In addition, the MFA results supported the pooling of all three coastal areas (see Section 3.1). GAMs were calculated and visualised using functionalities of the 'INDperform' package [78].

\section{Results}

\subsection{Environmental Gradients}

According to MFA results, the Gulf of Riga open waters are notably different from all of the studied coastal areas based on differences in hydrological conditions, cyanobacterial dominance (cyano:other ratio), abundance of mesozooplankton functional groups, and mesozooplankton FD indices (SESFRic, FEve, SESFDiv, and SESFDis). SST (the main driver of Dim1; Table 4) and cyano:other ratio (the main driver of Dim2; Table 4) showed evident 
increasing values from coastal areas to open waters (Figure 2). Salinity gradient, although irrelevant for Dim1 and Dim2, was represented in Dim3 and Dim4 (Table 4) and it showed a negative correlation to G3 and G1 abundances (Figure 2B).

The ensemble of mesozooplankton FD indices showed increased values in open waters compared to coastal areas (Figure 2C,D), except SESFRic which contributed weakly to the first two MFA dimensions ( $<2 \%$; Table 4$)$. Abundances of the G1 and G3 functional groups were negatively correlated with SESFRic (Figure 2B). Indices FEve and SESFDis contributed to Dim $1(19.4 \%$ and $15.0 \%$, respectively; Table 4$)$, which related to temperature gradient. SESFDiv and SESFDis were important factors for Dim2 $(11.5 \%$ and $10.7 \%$, respectively; Table 4) indicating an increase in mesozooplankton functional divergence and dispersion towards open waters.

(A)

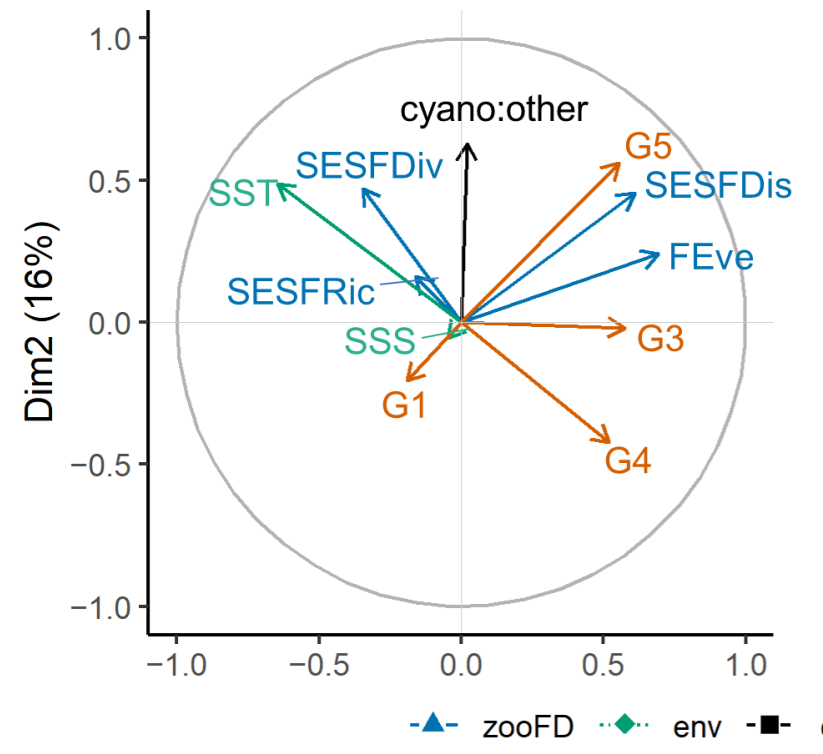

(C)

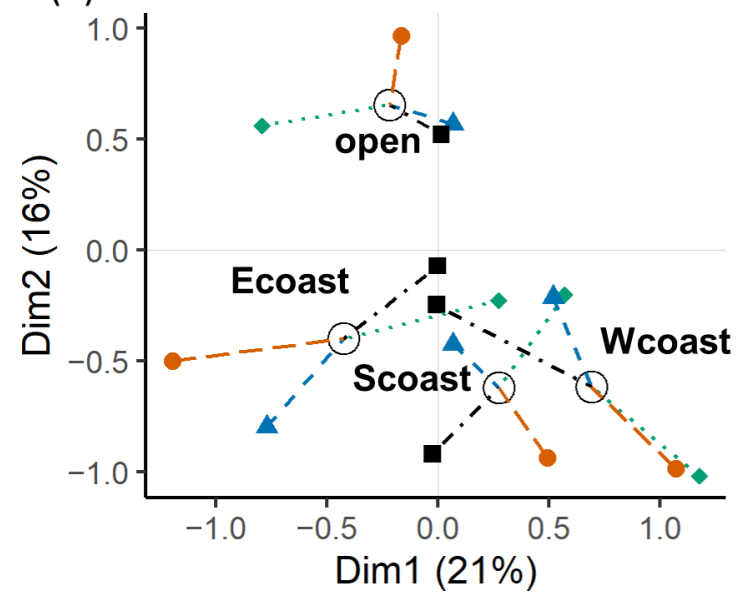

(B)

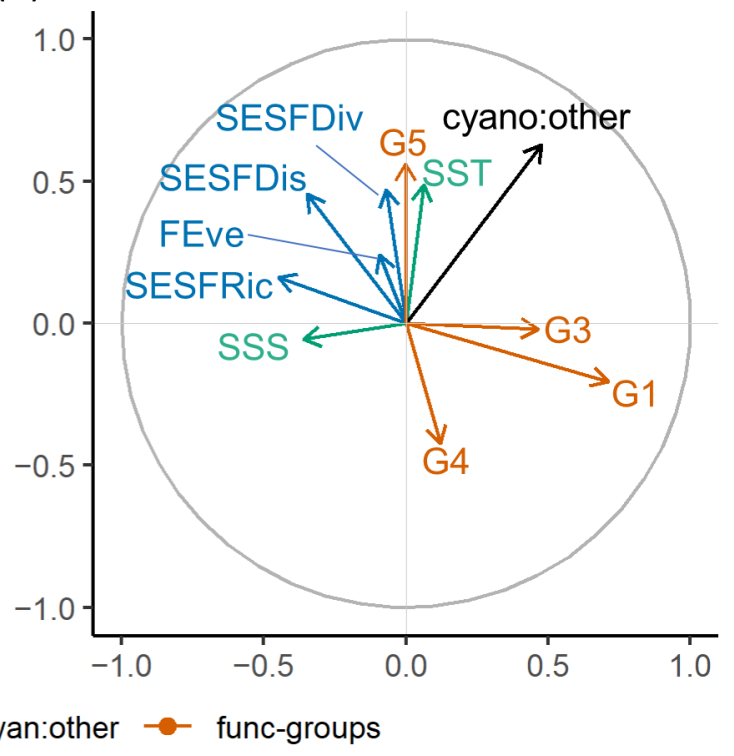

(D)

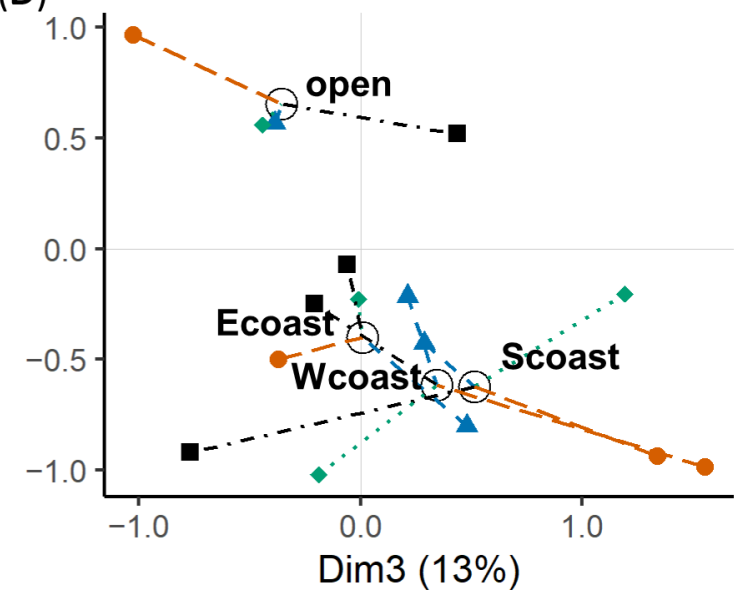

Figure 2. (A,B) Environmental gradients in the Gulf of Riga represented as a correlation circle and (C,D) environmental characteristics within each study area: open—open water area; Ecoast—eastern coastal area; Scoast—southern coastal area; Wcoast-western coastal area. Subgraphs $(\mathbf{A}, \mathbf{C})$ show results for Dim1 and Dim2; subgraphs (B,D) show results for Dim3 and Dim2. The percentage variability of the data set represented by dimensions are shown in parenthesis. Colours indicate grouping of variables. zooFD (mesozooplankton functional diversity indices): SESFRic, FEve, SESFDiv, and SESFDis; env (environmental abiotic factors): SST—surface $(0-10 \mathrm{~m})$ temperature, SSS—surface (0-10 m) salinity; cyan:other (cyanobacteria-to-other phytoplankton biomass ratio); func-groups (mesozooplankton functional groups) as defined in Table 3. 
Characteristics of mesozooplankton FD and other environmental factors (Figure 2) were similar between all coastal areas. Thus, data from eastern, southern, and western coastal sites were pooled into one data set for further analyses representing the coastal region in general.

Table 4. Relative contribution of parameters to Multiple Factor Analysis dimensions (Dim). Contributions $>10 \%$ are bolded. Explained variance of every Dim noted in the last row. All values in $\%$.

\begin{tabular}{cccccc}
\hline Parameter & Dim1 & Dim2 & Dim3 & Dim4 & Dim5 \\
\hline SESFRic & 1.0 & 1.4 & $\mathbf{1 2 . 7}$ & 4.9 & $\mathbf{4 5 . 6}$ \\
FEve & $\mathbf{1 9 . 4}$ & 3.0 & 0.5 & 0.0 & 4.2 \\
SESFDiv & 4.9 & $\mathbf{1 1 . 5}$ & 0.3 & 0.7 & $\mathbf{2 7 . 3}$ \\
SESFDis & $\mathbf{1 5 . 0}$ & $\mathbf{1 0 . 7}$ & 7.7 & 1.9 & 0.1 \\
SSS & 0.1 & 0.2 & $\mathbf{1 0 . 4}$ & $\mathbf{5 9 . 3}$ & 0.7 \\
SST & $\mathbf{2 1 . 1}$ & $\mathbf{1 5 . 5}$ & 0.3 & 9.6 & 1.5 \\
Cyano:other & 0.0 & $\mathbf{2 9 . 6}$ & $\mathbf{2 0 . 7}$ & $\mathbf{2 0 . 6}$ & $\mathbf{1 2 . 4}$ \\
G1 & 1.5 & 2.2 & $\mathbf{3 2 . 6}$ & 0.4 & 0.3 \\
G3 & $\mathbf{1 3 . 5}$ & 0.0 & $\mathbf{1 3 . 8}$ & 0.2 & 2.3 \\
G4 & $\mathbf{1 1 . 0}$ & 9.4 & 1.0 & 0.0 & 5.0 \\
G5 & $\mathbf{1 2 . 5}$ & $\mathbf{1 6 . 6}$ & 0.0 & 2.2 & 0.6 \\
\hline expl.variance & $\mathbf{2 0 . 7}$ & $\mathbf{1 6 . 1}$ & $\mathbf{1 3 . 1}$ & $\mathbf{1 2 . 0}$ & 8.3 \\
\hline
\end{tabular}

\subsection{Long Term Dynamics}

Herbivorous filter-feeders (G1) dominated the pelagic ecosystem of the Gulf of Riga in both coastal and open waters during the studied period (Figure 3). Small omnivores (G4) were the second most frequent functional group but G5 (that mostly consisted of calanoid E. affinis) was found in lesser amounts, similarly as large omnivores (G3).

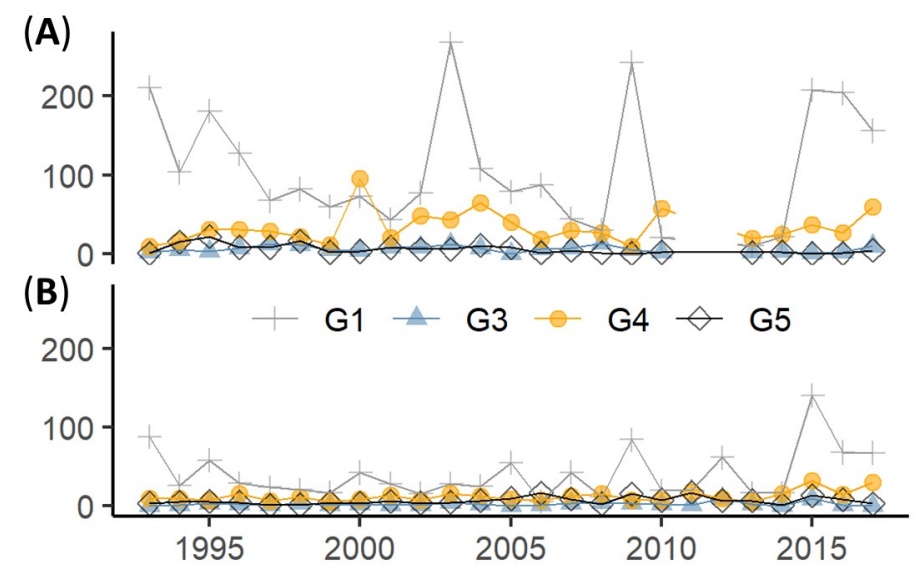

Figure 3. Long-term abundances of mesozooplankton functional groups in the Gulf of Riga coastal (A) and open (B) areas. Values shown as 1000 ind m-3. Functional groups (G1, G3, G4, and G5) are described in Table 3.

The temporal variability of mesozooplankton abundance was higher in coastal waters while the number of observed taxa was rather stable but slightly lower than in open waters (Figure 4A). SESFRic was almost identical in coastal and open waters (Figure 4C) and had low values in the early and mid 1990s. After a rapid increase towards the 2000s, SESFRic values stabilised and stayed approximately the same thenceforth. A minor decrease in SESFRic occurred during 2014-2017 (Figure 4C), seemingly mirroring the decrease in the number of observed taxa (Figure $4 \mathrm{~A}$ ) and the rapid increase in the total abundance of zooplankters (Figure 4B). 
FEve varied annually in both open and coastal areas without an evident trend (Figure 4D). SESFDiv values were high during the late 1990s and early 2000s, indicating that the mesozooplankton community consisted of functional groups that were more distinct from one another (located closer to the extreme ends of the trait space). After the year 2002, the distinction between functional groups slightly decreased implying that the abundant traits are becoming more similar (Figure 4E).
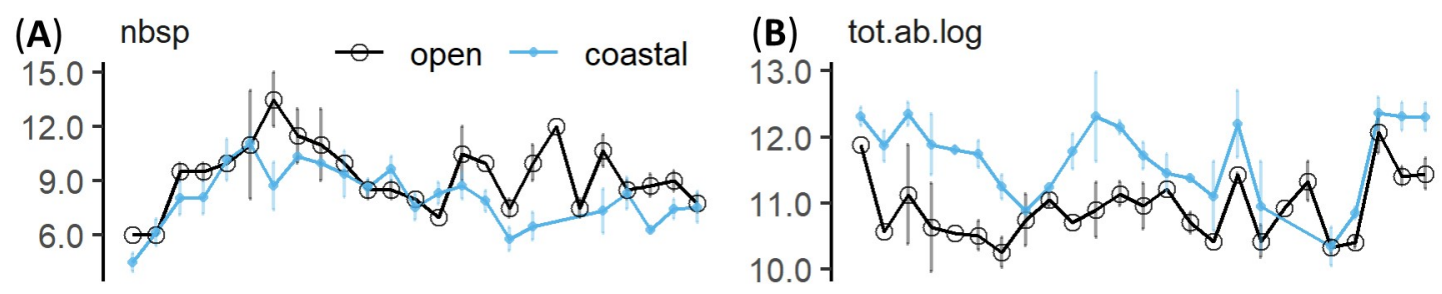

(C) SESFRic

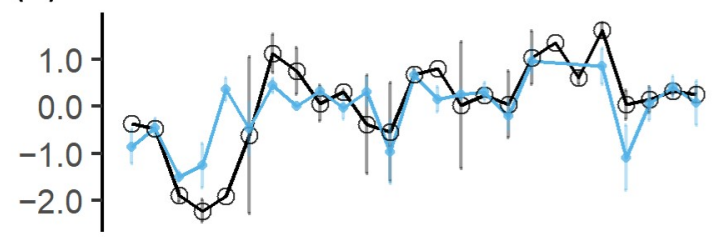

(D) FEve

(E) SESFDiv
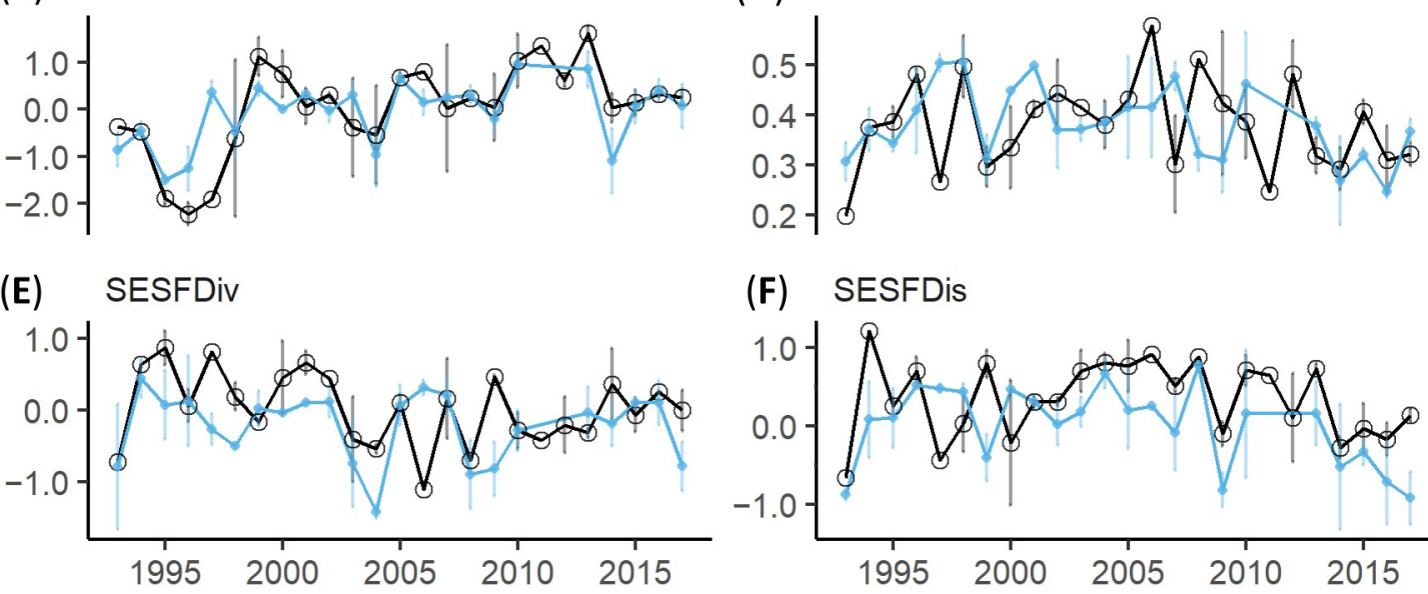

(F) SESFDis

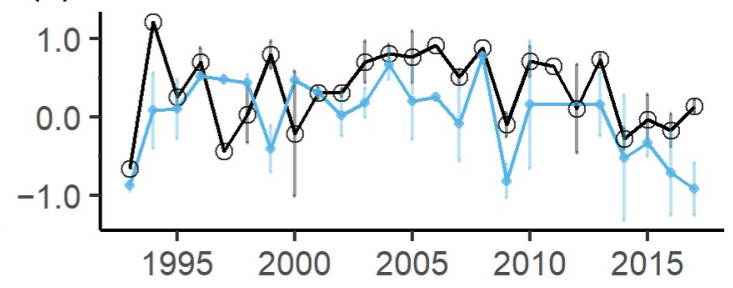

Figure 4. Long-term dynamics of summer mesozooplankton communities in open and coastal areas (mean of western, eastern, and southern coastal area) of the Gulf of Riga. Error bars represent the standard deviation of the mean. (A) nbspnumber of observed taxa; (B) tot.ab.log—natural log of total abundance; (C) SESFRic—functional richness; (D) FEvefunctional evenness; (E) SESFDiv—functional divergence; (F) SESFDis—functional dispersion.

Based on SESFDis values, mesozooplankton communities in coastal areas appeared functionally less dispersed than those in open areas. However, annual dynamics were similar between area type, noting that the responses to disturbances were most likely analogous. From 2003 to 2008, SESFDis showed continuously high values indicating the most functionally diverse period (considering the traits included in the analysis) (Figure $4 \mathrm{~F}$ ).

\subsection{Mesozooplankton FD Responses to Environmental Factors}

In the coastal areas, SESFRic and FEve indices responded negatively to an increase in herring biomass (both total biomass and spawning biomass) (Figure 5A,B,E,F) and herbivorous filter-feeders (Figure 5C) whereas high numbers of G5 zooplankters had a positive impact (Figure 5H). Additionally, FEve decreased with increasing SST (Figure 5G). The least responsive FD index SESFDiv exhibited only one weak relationship and that was in relation to the abundance of G4 (Figure 5I). Conversely, SESFDis responded to cyanobacterial dominance (Figure 5J) and to abundances of all included mesozooplankton groups (G1, G3-5; Figure 5K-N). Despite the observed wide variety of response relationships only, three of them demonstrated acceptable predictive ability (nrmse < 1.0; Figure 5A,H,I).

In open waters, SESFRic negatively correlated with salinity (Figure 6A); although the response was almost linear (edf $=1.17)$ and significant $(p=0.010)$, its predictive ability was extremely low $(\mathrm{nrmse}=17.541)$. Herring recruitment and spawning biomass demonstrated contradicting impact on the FEve index (Figure 6B,C). Increasing herring recruitment had 
a positive effect on FEve, whereas increasing spawning biomass had a negative impact. Additionally, FEve was positively related to an abundance of G3 (Figure 6D). The SESFDis index reacted to dynamics of mesozooplankton functional groups (Figure 6E-G), but SESFDiv did not respond to any of the factors included in the analysis.

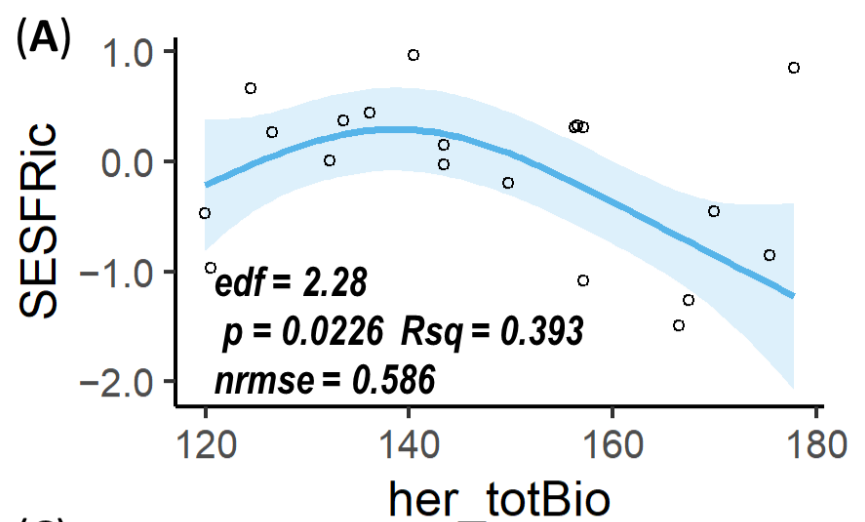

(C)

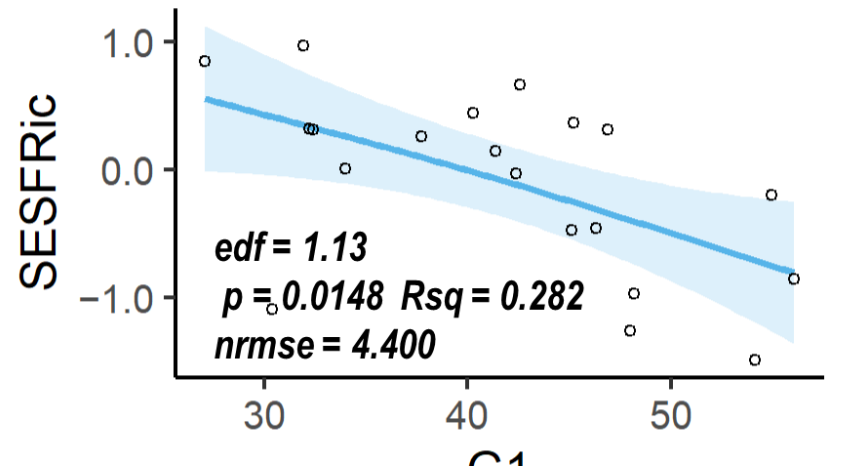

(E)

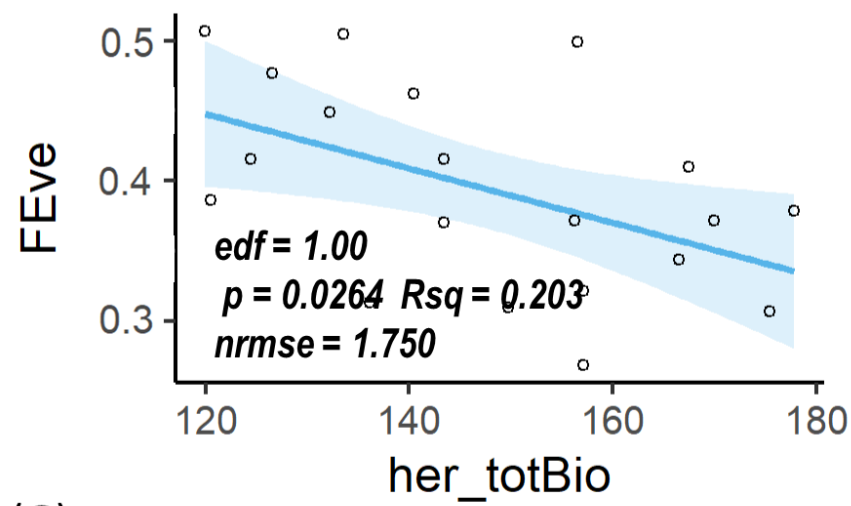

(G)

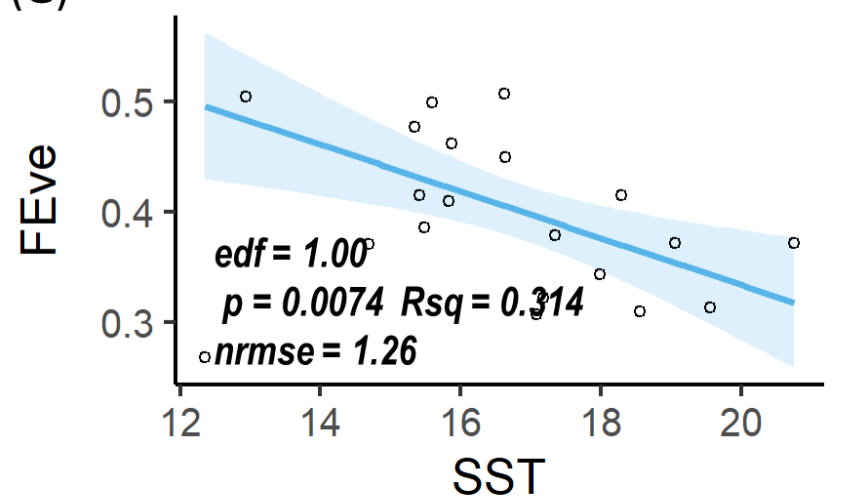

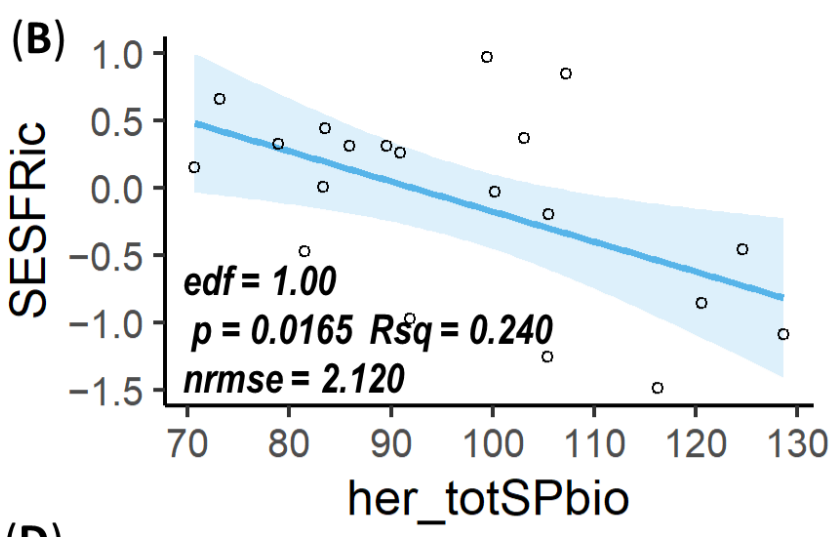

(D)

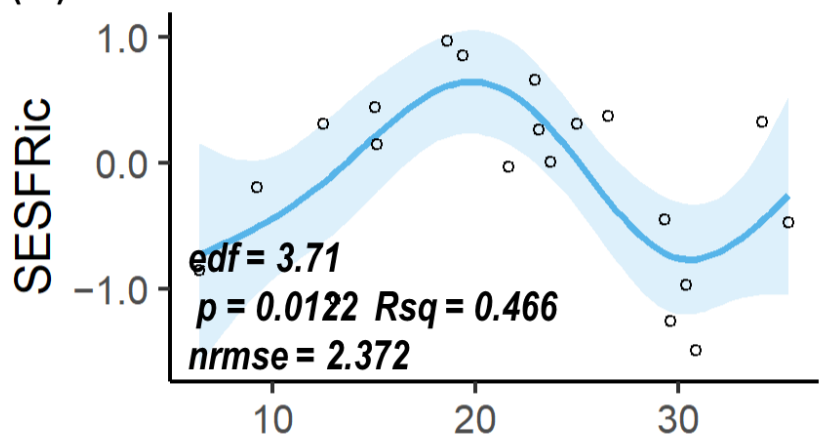

(F)
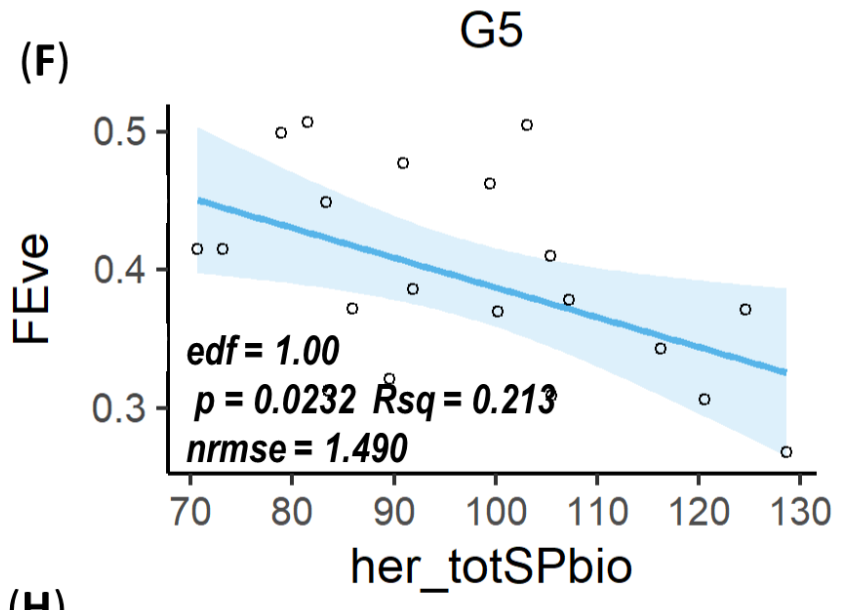

(H)

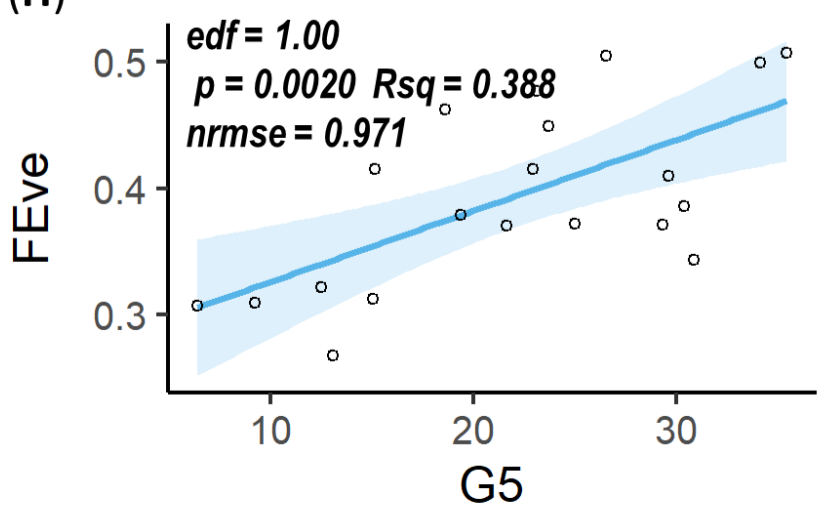

Figure 5. Cont. 
(I)

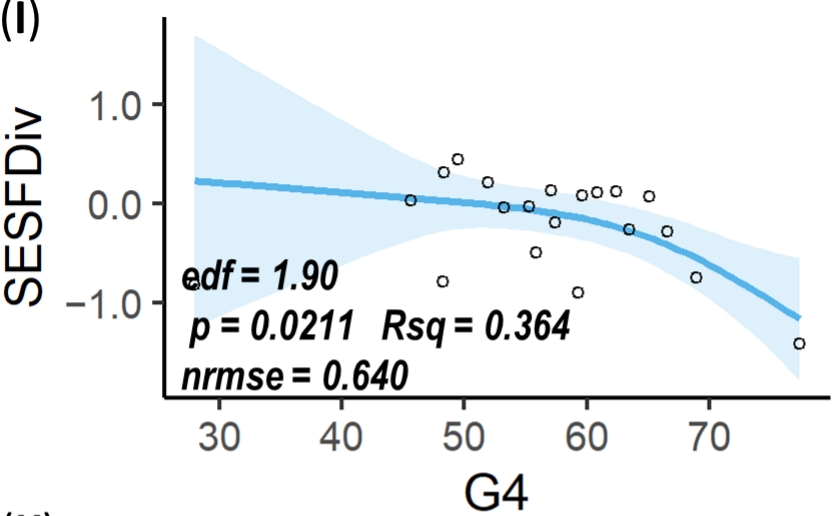

(K)

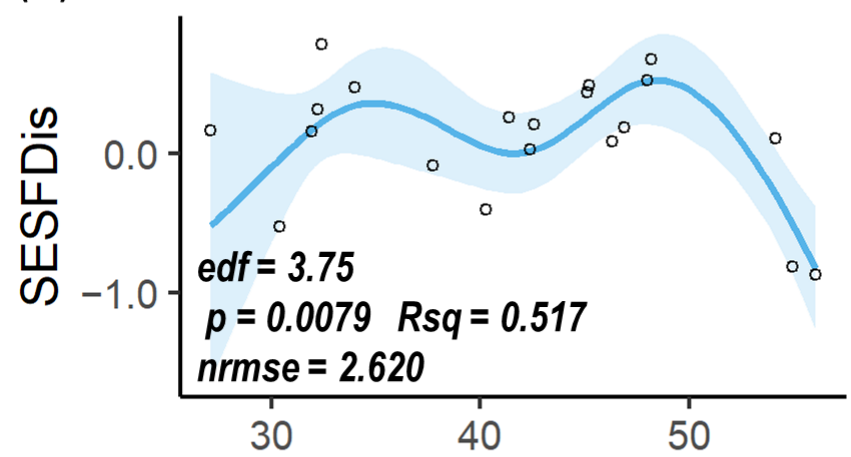

(M)

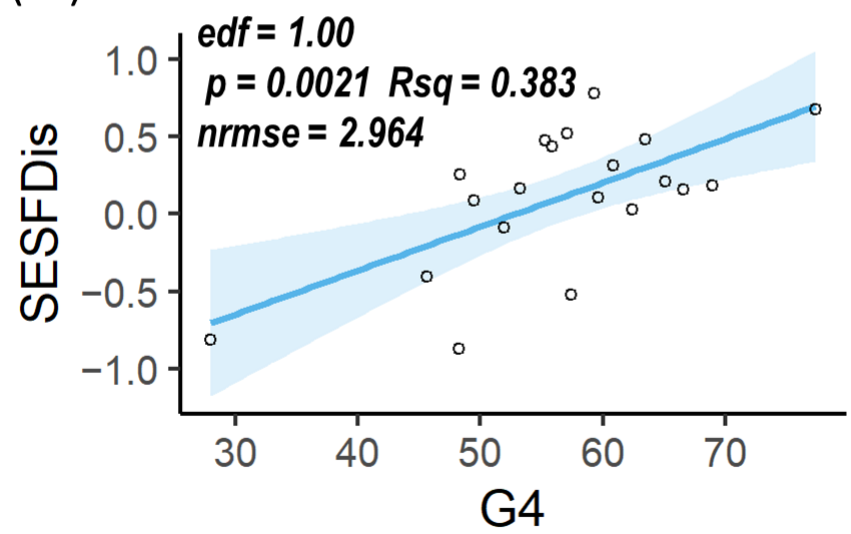

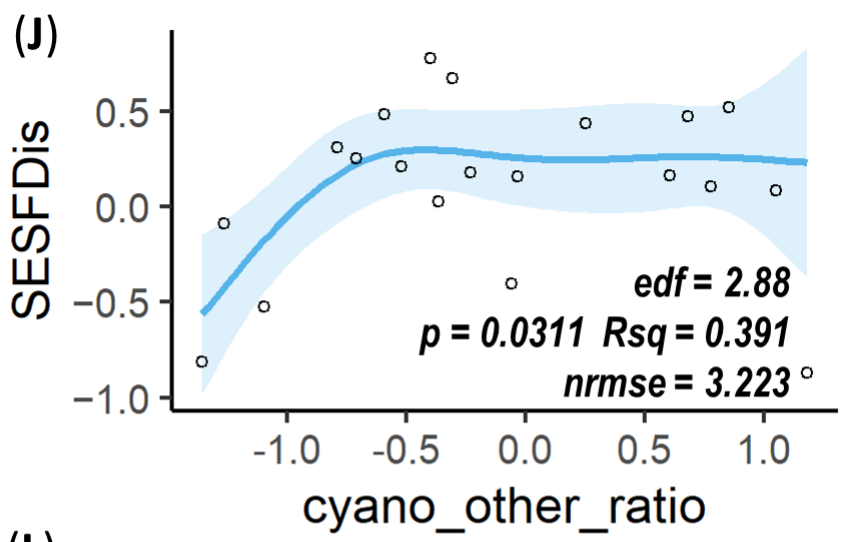

(L)

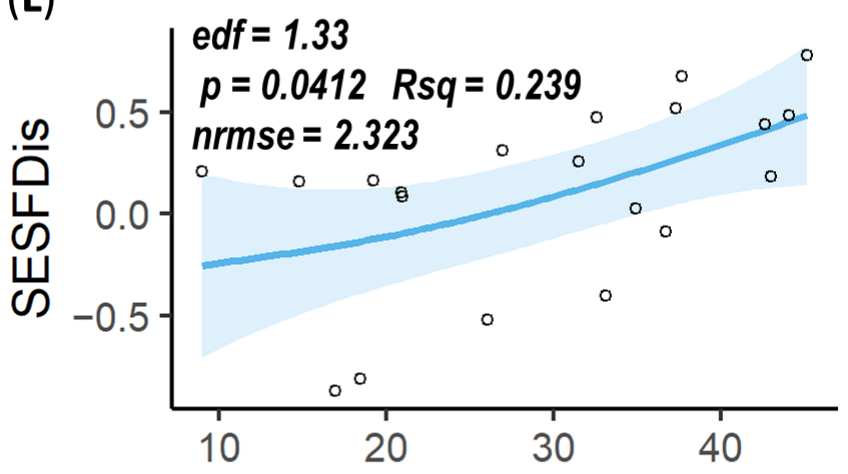

(N)

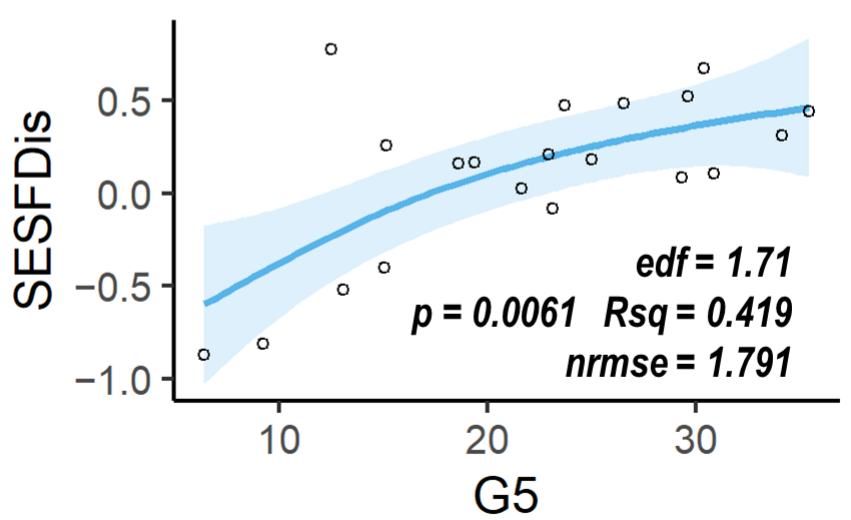

Figure 5. Response curves from the generalised additive models (GAM) based on test data (1993-2014) of the Gulf of Riga coastal waters. Only models with $p \leq 0.05$ are shown. Subgraphs (A-D) show responses to environmental drivers of SESFRic (functional richness), (E-H) FEve (functional evenness), (I) SESFDiv (functional divergence), and (J-N) SESFDis (functional dispersion) indices. edf-estimated degrees of freedom for the model terms; $p$-the $p$ value for the smoothing term (Rsq-adjusted R-squared for the models; nrmse-absolute values of the root mean square error normalised by the standard deviation, based on test data (2015-2017). her_totBio-total herring biomass, 1000 tonnes; her_totSPbio-herring spawning biomass, 1000 tonnes; cyano_other_ratio-cyanobacteria-to-other phytoplankton biomass ratio, box-cox transformed; G1-G5-abundance of group G1-G5, box-cox transformed (functional groups are described in Table 3); SST-sea surface temperature, ${ }^{\circ} \mathrm{C}$. 
(A)

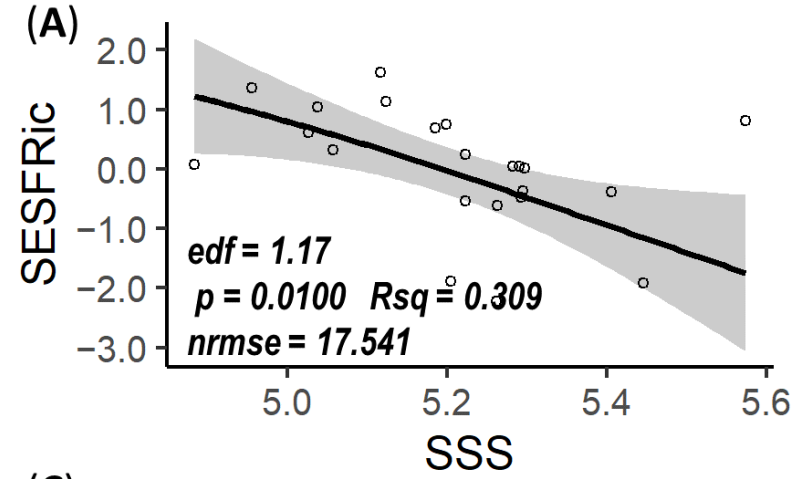

(C)

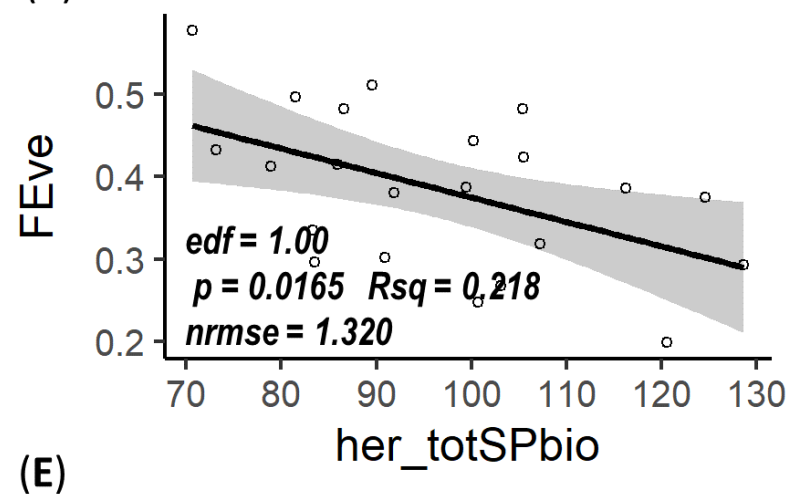

(E)

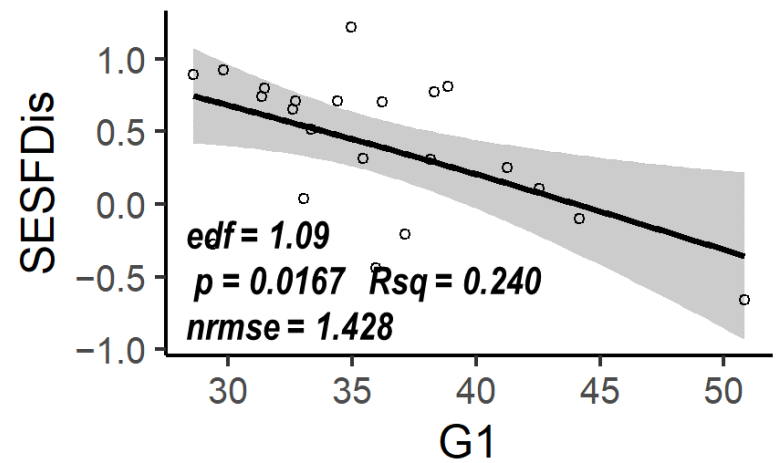

(G)

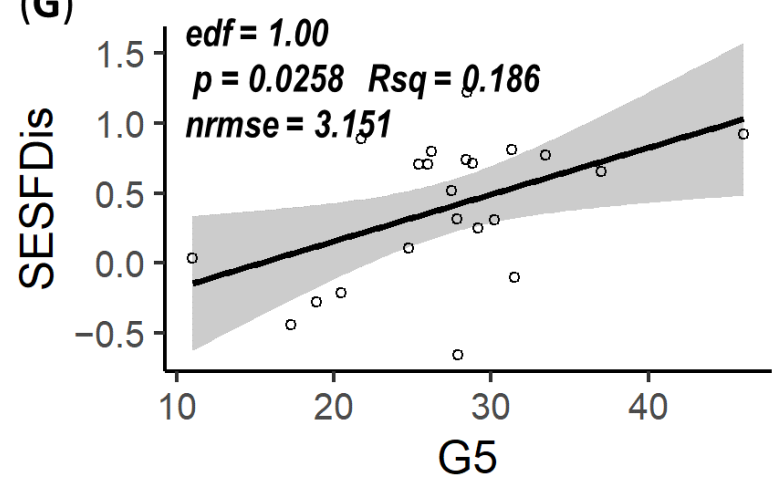

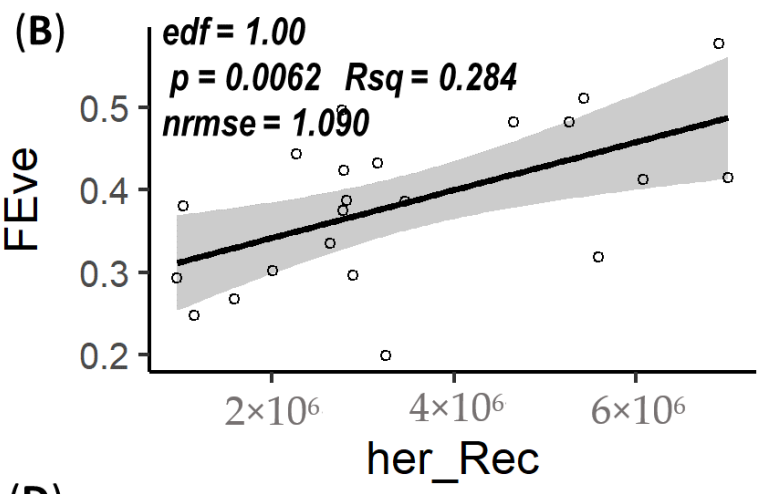

(D)

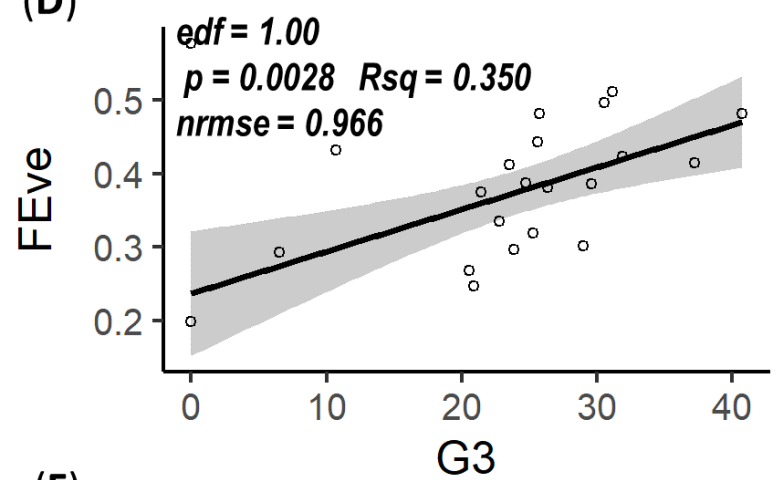

(F)

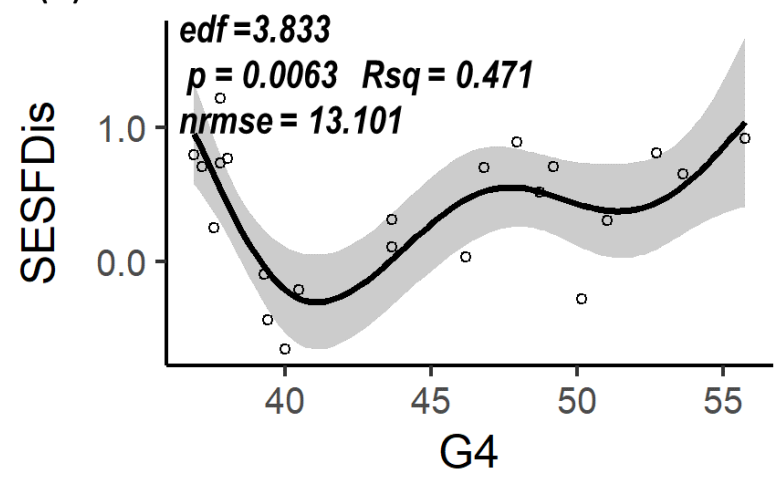

Figure 6. Response curves from the Generalised Additive Models (GAM) based on test data (1993-2014) of the Gulf of Riga open waters. Only models with $p \leq 0.05$ are shown. Subgraph (A) shows response to environmental drivers of SESFRic (functional richness), subgraphs (B-D) show responses of FEve (functional evenness), and (E-G) SESFDis (functional dispersion) indices. edf-estimated degrees of freedom for the model terms; $p$ - the $p$ value for the smoothing term; Rsqadjusted R-squared for the models; nrmse-absolute values of the root mean square error normalised by the standard deviation, based on test data (2015-2017); her_Rec-number of herring recruitment (age 1), 1000 ind; her_totSPbio-herring spawning biomass, 1000 tonnes; G1-G5-abundance of group G1-G5, box-cox transformed (functional groups are described in Table 3); SSS-sea surface salinity, PSU. 


\section{Discussion}

Differences in mesozooplankton FD and their responses to environmental factors were considerable between coastal $(<15 \mathrm{~m})$ and open waters of the shallow brackish Gulf of Riga. Coastal areas were lower in mesozooplankton FD but higher in total zooplankter numbers (Figure 4), whereas the mesozooplankton community in the open waters appeared to be more resilient to local disturbances as the amount of significant responses were half the number of those found in coastal areas (Figures 5 and 6).

Several studies conducted in brackish habitats have reported a decrease in diversity along the salinity gradient, linking increased plankton diversity to an intermediate salinity zone (5-8 PSU) $[14,79,80]$, i.e., the salinity of the Gulf of Riga open waters. The intermediate disturbance hypothesis $[81,82]$ is in agreement with the observations; it states that species diversity is highest at intermediate disturbance levels due to reduced species densities that weakens interspecific competition allowing less-opportunistic and less-adapted species to survive. However, the results of the present study do not indicate salinity gradient as statistically important for the differences between open and coastal areas in the Gulf of Riga (Figure 2B, Table 4). Besides the low salinity, the coastal waters of the Gulf of Riga are highly impacted by wind and can be defined as a profoundly fluctuating habitat, conversely to open waters. The high freshwater impact also reinforces mixing and turbulence in the area. Riverine discharge is spread along the eastern and western coastal areas almost equally during summer [83]. Most likely, these are the features responsible for the identified similarities between the studied coastal sites and their differences to open waters (Figure 2).

Environmental filtering is particularly pronounced in dynamic and fluctuating waters, yet it has been demonstrated that they are also highly productive habitats with effective food webs and intensive biotic interactions [30]. The majority of identified relationships between coastal mesozooplankton FD and environmental drivers were responses to biotic parameters. The only exception was functional evenness (FEve) that showed a significant $(p=0.0074)$ and accurate (nrmse $=1.26)$ negative relationship to abiotic conditions, namely, SST (Figure 5G). A decrease in the balance of the filled niche space of the mesozooplankton community (described by FEve) with increasing temperature is a direct manifestation of abiotic filtering under the fluctuation of seasonal forcing. The benefits from warmer or colder conditions differ between mesozooplankton species, consequently creating shifts in species and trait occurrences (e.g., $[84,85])$.

As previously mentioned, the strength of interspecific competition is also a significant aspect of FD variation. Helenius et al. [14] reported lower zooplankton FD based on feeding traits at sites where Keratella rotifers or calanoid copepods were prevailing. In the present study, coastal areas were dominated by herbivorous filter-feeders (G1 functional group), including Keratella species, and cruising small-sized omnivores (G4 functional group) that comprise Synchaeta rotifers and Copepoda nauplii (Figure 3A), thus mirroring the patterns identified in the Gulf of Finland [14].

Both groups G1 and G4 are comparatively small-sized and body size is considered a master trait that defines the main physical abilities and constraints of an organism [86], including its power to retain horizontal and vertical position in the water mass (increasing with size) [87]. Plausibly, the aggregation of non-migrating small-size taxa in the water column is also supported by enhanced jet-like currents that are present in the Gulf of Riga within western and eastern coastal areas during the summer period [83]. Kahru et al. [88] have analysed physical-biological coupling in frontal structures in the Baltic Sea. They found indeed small-sized zooplankters, namely Bosmina and Synchaeta, as a dominating taxa in the fronts and noted the increased zooplankton abundances in the regions, which was explained by particle aggregations due to flow convergence. However, these are still a matter of speculation and only a focused study on the physical processes and their biological implications within the above-mentioned currents of the Gulf of Riga would give more profound information.

The majority of the taxa within groups G1 and G4 have short life cycles (except for Copepoda nauplii and meroplankton that are ephemeral development stages) and the 
ability of parthenogenetic reproduction (rotifers, cladocerans), which allows for rapid development under suitable conditions and consecutive triumph in competitive encounters [89]. Another factor affecting the abundance of coastal zooplankton can be recruitment from the dormant stages of plankters or resting eggs [90]. However, the sediment type of the coastal area, i.e., sand, does not support accumulation of resting eggs. All sedimenting material are transported to deeper accumulation zones during the autumn convection of the water column [91].

The abundance of group G4 negatively affected functional divergence (SESFDiv) of the mesozooplankton community (Figure 5I). Functional divergence has been identified as a descriptor for niche differentiation, thus resource availability and competition within a filled trait space [72]. Therefore, the identified negative relationship builds up to the reason that the competition over resources is a significant driver for the mesozooplankton FD in the coastal Gulf of Riga, especially at times when a rapidly-developing functional group dominates the community. All other observed relationships between groups G1, G4, and FD indices showed limited predictive power (nrmse $\gg 1$; Figure $5 \mathrm{C}, \mathrm{K}, \mathrm{M}$ ) or were hardly interpretable (multimodal; Figure $5 \mathrm{~K}$ ) implying non-causal relationships. Although, in one instance, the G4 group had a positive effect on functional dispersion (SESFDis) (Figure 5M).

Considering the typical summer composition of phytoplankton, prey availability and its quality was expressed as cyanobacterial dominance (cyano:other ratio) in the present study. Cyanobacterial blooms may cause a negative impact on zooplankton diversity due to inhibition $[92,93]$ and low nutritional quality $[94,95]$. Moreover, feeding on colony- and filament-forming dense aggregations (e.g., Aphanizomenon flosaquae - prevailing species in the Gulf of Riga) is challenging for zooplankton and can result in mechanistic damage to the feeding apparatus [96]. Contrarily, several Copepoda species are ecologically adapted to feed on cyanobacteria [33,97]. Thus, combined effects can result in modified FD of mesozooplankton during cyanobacterial blooms as reported from freshwater ecosystems [98].

However, FD indices of open water communities did not respond to variability of cyanobacterial dominance in the present study (Figure 6) despite the overall high eutrophication level of the Gulf of Riga. Whereas the cyano:other ratio had a positive effect on functional dispersion (SESFDis) of coastal communities when the ratio was low (Figure 5J), i.e., non-blooming periods. At the same time, no negative impact during blooms was observed. Still, this relationship had limited predictive power (nrmse $=3.223$ ). The functional dispersion (SESFDis) index describes niche complementarity and is a recommended metric for the detection of assembly processes [5]. Therefore, we argue that cyanobacteria had no pronounced adverse effect on mesozooplankton FD in the Gulf of Riga during the studied period. Indeed, during cyanobacterial dominance, up to $75 \%$ of the primary production can be transferred via microbial loop $[31,99]$ meeting the energy demand for mesozooplankton needs.

Still, an important aspect of the interpretation of the present results is the long-term ecosystem view of the region. The studied data (1993-2017) cover a period after the Baltic Sea regime shift [100] and analyse a situation when planktivorous flows dominated the food web of the Gulf of Riga [101]. Beforehand, detritivorous flows were prevailing and they were supported by higher diatom biomass $[38,101]$. Thus, the present results describe a relatively stable period, from the perspective of the phytoplankton community, limiting the opportunities for identification of phytoplankton-induced impacts on zooplankton FD. The study by Jansson et al. [15] described mesozooplankton FD in relation to abiotic factors covering the period from 1960, including the regime shift. They identified a gradual decrease in the number (richness) of functional groups of summer mesozooplankton in the Gulf of Riga until the early 1990s, but it was followed by a rapid increase (a similar pattern was also observed in the present study; see Figure 4C). What is noteworthy is that several non-indigenous species invaded the Baltic Sea (e.g., cladocerans Cercopagis pengoi, Evadne anonyx, and polychaeta Marenzelleria viridis) in the 1990s and early 2000s [102] adding to the disturbances but, at the same time, increasing species richness (Figure 4C) and FD [19]. Cladoceran C. pengoi, detected in the Gulf of Riga in 1992, has an evident impact on the 
pelagic food web [103] as it competes with planktivorous fish for larger mesozooplankton prey (groups G3 and G5; Table 3) and graze upon small-sized zooplankters (groups G1 and G4; Table 3) [104,105] whilst serving as a food source for herring [103,104].

Top-down control also appeared to be influential on mesozooplankton FD in the Gulf of Riga. Both total herring biomass and spawning stock biomass showed a negative impact on functional richness (SESFRic) and evenness (FEve) in coastal areas (Figure 5A,B,E,F) and spawning biomass almost equally affected FEve in open waters. This pattern could be explained by the selective feeding of the herring, which tend to target larger zooplankters (G5 functional group; Table 3), especially calanoid copepods Eurytemora affinis and Limnocalanus macrurus [26]. The observed positive relationship between abundances of the G5 functional group and FD of coastal and open water mesozooplankton (Figures 5H,N and 6G) adds to the credibility of this conclusion.

Since coastal areas serve as primary feeding grounds for larvae and young herring, we anticipated a significant impact on mesozooplankton FD in relation to herring recruitment in these areas [106]. Young herring in the Gulf of Riga prey upon various zooplankters, including cladocerans and copepods, but mainly prefer E. affinis [107]. Thus, it is plausible that larvae and young herring are not food-limited in coastal areas, which could explain the lack of a significant impact on coastal mesozooplankton FD. Alternatively, they may have already left for deeper waters by the time sampling occurred, as suggested by observed positive relationship between herring recruitment and functional evenness (FEve) of mesozooplankton communities in open waters (Figure 6B).

The opposing impacts of spawning stock biomass or total herring biomass and herring recruitment on mesozooplankton functional evenness is unexpected. Yet, it can be explained by the broader scope of prey available for adult herring compared to younger fish resulting in more targeted feeding on the G5 mesozooplankton functional group [26,108]. In other words, adult herring will prey upon larger copepods and cladocerans only and will switch to other prey such as mysids or amphipods if the preferred zooplankton are in sub-optimal densities [108]. Conversely, young herring tend to be less capable of switching prey [108]. Additionally, the visibility is reduced in coastal areas due to the influence of opaque freshwaters reducing the abilities of visual predators [46]. Consequently, fish larvae and young fish are, most likely, forced to feed on what is available even if it is not their preferred prey, affecting the mesozooplankton community in a more balanced way than adult herring.

In conclusion, we can argue that biotic factors are important drivers shaping mesozooplankton FD in the shallow brackish Gulf of Riga during summer. Competition and resource availability in combination with hydrodynamic features were seemingly the central structuring mechanisms behind the dynamics of coastal mesozooplankton FD, although predation by adult herring was also identified as a significant driver. Predation by young herring was solely impacting mesozooplankton in open waters, implying either weaker predation on mesozooplankton or non-limiting prey availability in the coastal areas. The absence of the mesozooplankton FD response to cyanobacterial dominance was slightly surprising and our understanding of this relationship would benefit from a more comprehensive study of bottom-up effects on mesozooplankton FD in the Gulf of Riga.

Supplementary Materials: The following are available online at https:/ / www.mdpi.com/article / 10.3390/w13141881/s1, Data S1: Annual means (1993-2017) of environmental variables describing coastal (western, southern, and eastern areas) and open (stations O1-O4) habitats of the Gulf of Riga. The data describe mesozooplankton communities (number of species, functional diversity indices, total abundance and abundance of functional groups), abiotic conditions (sea surface temperature and salinity) and cyanobacteria-to-other phytoplankton taxa biomass ratio.

Author Contributions: Conceptualisation, A.L.; Formal analysis, A.L.; Funding acquisition, J.A.; Methodology, A.L.; Supervision, A.I. and J.A.; Visualisation, A.L.; Writing-original draft, A.L.; Writing-review \& editing, A.I., I.J. and J.A. All authors have read and agreed to the published version of the manuscript. 
Funding: This work was supported by the Ministry of Environmental Protection and Regional Development, project no. IL/106/2017 "Improvement of knowledge of the state of the marine environment in the marine waters under the jurisdiction of Latvia".

Institutional Review Board Statement: Not applicable.

Informed Consent Statement: Not applicable.

Data Availability Statement: The data (except for herring population parameters) presented in this study are available in the Supplementary Material Data S1.

Acknowledgments: The sampling was performed under the Latvian Marine Monitoring Programme. We are grateful to our past and present colleagues from the Latvian Institute of Aquatic Ecology for field work and maintenance of a long-term database. We also thank the anonymous reviewers for their comments and Nicholas A. Heredia for revising the English.

Conflicts of Interest: The authors declare no conflict of interest.

\section{References}

1. Chapin, F.S.I.; Reynolds, H.L.; D'Antonio, C.M.; Eckhart, V.M. The functional role of species in terrestrial ecosystems. In Global Change and Terrestrial Ecosystems; Walker, B., Steffen, W., Eds.; Cambridge University Press: Cambridge, UK, 1996 ; pp. 403-428.

2. Menge, B.A.; Olson, A.M. Role of scale and environmental factors in regulation of community structure. Trends Ecol. Evol. 1990, 5, 52-57. [CrossRef]

3. Diaz, S.; Cabido, M. Vive la différence: Plant functional diversity matters to ecosystem processes. Trends Ecol. Evol. 2001, 16, 646-655. [CrossRef]

4. Petchey, O.L.; Gaston, K.J. Functional diversity (FD), species richness and community composition. Ecol. Lett. $2002,5,402-411$. [CrossRef]

5. Mason, N.W.; de Bello, F.; Mouillot, D.; Pavoine, S.; Dray, S. A guide for using functional diversity indices to reveal changes in assembly processes along ecological gradients. J. Veg. Sci. 2013, 24, 794-806. [CrossRef]

6. Pecuchet, L.; Lindegren, M.; Hidalgo, M.; Delgado, M.; Esteban, A.; Fock, H.O.; Gil de Sola, L.; Punzón, A.; Sólmundsson, J.; Payne, M.R. From traits to life-history strategies: Deconstructing fish community composition across European seas. Glob. Ecol. Biogeogr. 2017, 26, 812-822. [CrossRef]

7. Hooper, D.U.; Chapin, F., III; Ewel, J.J.; Hector, A.; Inchausti, P.; Lavorel, S.; Lawton, J.H.; Lodge, D.; Loreau, M.; Naeem, S.; et al. Effects of biodiversity on ecosystem functioning: A consensus of current knowledge. Ecol. Monogr. 2005, 75, 3-35. [CrossRef]

8. Mouillot, D.; Graham, N.A.; Villéger, S.; Mason, N.W.; Bellwood, D.R. A functional approach reveals community responses to disturbances. Trends Ecol. Evol. 2013, 28, 167-177. [CrossRef]

9. Folke, C.; Carpenter, S.; Walker, B.; Scheffer, M.; Elmqvist, T.; Gunderson, L.; Holling, C.S. Regime shifts, resilience, and biodiversity in ecosystem management. Annu. Rev. Ecol. Evol. Syst. 2004, 35, 557-581. [CrossRef]

10. Vallina, S.M.; Cermeno, P.; Dutkiewicz, S.; Loreau, M.; Montoya, J.M. Phytoplankton functional diversity increases ecosystem productivity and stability. Ecol. Model. 2017, 361, 184-196. [CrossRef]

11. Litchman, E.; Ohman, M.D.; Kiørboe, T. Trait-based approaches to zooplankton communities. J. Plankton Res. 2013, 35, 473-484. [CrossRef]

12. Hébert, M.P.; Beisner, B.E.; Maranger, R. A meta-analysis of zooplankton functional traits influencing ecosystem function. Ecology 2016, 97, 1069-1080. [CrossRef]

13. Gomes, L.F.; Pereira, H.R.; Gomes, A.C.A.M.; Vieira, M.C.; Martins, P.R.; Roitman, I.; Vieira, L.C.G. Zooplankton functionalapproach studies in continental aquatic environments: A systematic review. Aquat. Ecol. 2019, 8, 191-203. [CrossRef]

14. Helenius, L.K.; Leskinen, E.; Lehtonen, H.; Nurminen, L. Spatial patterns of littoral zooplankton assemblages along a salinity gradient in a brackish sea: A functional diversity perspective. Estuar. Coast. Shelf Sci. 2017, 198, 400-412. [CrossRef]

15. Jansson, A.; Klais-Peets, R.; Grinienè, E.; Rubene, G.; Semenova, A.; Lewandowska, A.; Engström-Öst, J. Functional shifts in estuarine zooplankton in response to climate variability. Ecol. Evol. 2020, 10, 11591-11606. [CrossRef] [PubMed]

16. Lokko, K.; Virro, T.; Kotta, J. Seasonal variability in the structure and functional diversity of psammic rotifer communities: Role of environmental parameters. Hydrobiologia 2017, 796, 287-307. [CrossRef]

17. Pecuchet, L.; Lindegren, M.; Kortsch, S.; Całkiewicz, J.; Jurgensone, I.; Margonski, P.; Otto, S.A.; Putnis, I.; Strāke, S.; Nordström, M.C. Spatio-temporal dynamics of multi-trophic communities reveal ecosystem-wide functional reorganization. Ecography 2020, 43, 197-208. [CrossRef]

18. Ojaveer, H.; Jaanus, A.; Mackenzie, B.R.; Martin, G.; Olenin, S.; Radziejewska, T.; Telesh, I.; Zettler, M.L.; Zaiko, A. Status of biodiversity in the Baltic Sea. PLoS ONE 2010, 5, e12467. [CrossRef] [PubMed]

19. Snoeijs-Leijonmalm, P.; Andrén, E. Why is the Baltic Sea so special to live in? In Biological Oceanography of the Baltic Sea; Snoeijs-Leijonmalm, P., Schubert, H., Radziejewska, T., Eds.; Springer: Dordrecht, The Netherlands, 2017 ; pp. $23-84$. 
20. Andersen, J.H.; Axe, P.; Backer, H.; Carstensen, J.; Claussen, U.; Fleming-Lehtinen, V.; Järvinen, M.; Kaartokallio, H.; Knuuttila, S.; Korpinen, S.; et al. Getting the measure of eutrophication in the Baltic Sea: Towards improved assessment principles and methods. Biogeochemistry 2011, 106, 137-156. [CrossRef]

21. Andrushaitis, A. River load of eutrophying substances and heavy metals into the Gulf of Riga. In Ecosystem of the Gulf of Riga between 1920 and 1990; Ojaveer, E., Ed.; Estonian Academy Publishers: Tallinn, Estonia, 1995; pp. 32-40.

22. Ojaveer, E.; Lumberg, A.; Ojaveer, H. Highlights of zooplankton dynamics in Estonian waters (Baltic Sea). ICES J. Mar. Sci. 1998, 55, 748-755. [CrossRef]

23. Ikauniece, A. Long-term abundance dynamics of coastal zooplankton in the Gulf of Riga. Environ. Int. 2001, 26, 175-181. [CrossRef]

24. Kotta, J.; Kotta, I.; Simm, M.; Põllupüü, M. Separate and interactive effects of eutrophication and climate variables on the ecosystem elements of the Gulf of Riga. Estuar. Coast. Shelf Sci. 2009, 84, 509-518. [CrossRef]

25. Labuce, A.; Dimante-Deimantoviča, I.; Tunēns, J.; Strāḳe, S. Zooplankton indicator-based assessment in relation to site location and abiotic factors: A case study from the Gulf of Riga. Environ. Monit. Assess. 2020, 192, 147. [CrossRef]

26. Livdāne, L.; Putnis, I.; Rubene, G.; Elferts, D.; Ikauniece, A. Baltic herring prey selectively on older copepodites of Eurytemora affinis and Limnocalanus macrurus in the Gulf of Riga. Oceanologia 2016, 58, 46-53. [CrossRef]

27. Calbet, A. The trophic roles of microzooplankton in marine systems. ICES J. Mar. Sci. 2008, 65, 325-331. [CrossRef]

28. Johansson, M.; Gorokhova, E.; Larsson, U.L.F. Annual variability in ciliate community structure, potential prey and predators in the open northern Baltic Sea proper. J. Plankton Res. 2004, 26, 67-80. [CrossRef]

29. Motwani, N.H.; Duberg, J.; Svedén, J.B.; Gorokhova, E. Grazing on cyanobacteria and transfer of diazotrophic nitrogen to zooplankton in the Baltic Sea. Limnol. Oceanogr. 2018, 63, 672-686. [CrossRef]

30. Snoeijs-Leijonmalm, P. Patterns of biodiversity. In Biological Oceanography of the Baltic Sea; Snoeijs-Leijonmalm, P., Schubert, H., Radziejewska, T., Eds.; Springer: Dordrecht, The Netherlands, 2017; pp. 123-191.

31. Donali, E.; Olli, K.; Heiskanen, A.S.; Andersen, T. Carbon flow patterns in the planktonic food web of the Gulf of Riga, the Baltic Sea: A reconstruction by the inverse method. J. Mar. Syst. 1999, 23, 251-268. [CrossRef]

32. Filstrup, C.T.; Hillebrand, H.; Heathcote, A.J.; Harpole, W.S.; Downing, J.A. Cyanobacteria dominance influences resource use efficiency and community turnover in phytoplankton and zooplankton communities. Ecol. Lett. 2014, 17, 464-474. [CrossRef]

33. Hogfors, H.; Motwani, N.H.; Hajdu, S.; El-Shehawy, R.; Holmborn, T.; Vehmaa, A.; Engström-Öst, J.; Brutemark, A.; Gorokhova, E. Bloom-forming cyanobacteria support copepod reproduction and development in the Baltic Sea. PLoS ONE 2014, 9, e112692. [CrossRef]

34. Kornilovs, G.; Möllmann, C.; Sidrevics, L.; Berzinsh, V. Fish predation modified climate-induced long-term trends of mesozooplankton in a semi-enclosed coastal gulf. ICES CM 2004, 50, 13.

35. Simm, M.; Ojaveer, E. Dynamics of copepods and fish larvae in Pärnu Bay (NE part of the Gulf of Riga) in the spring-summer period. Proc. Est. Acad. Sci. Biol. Ecol. 2000, 49, 317-326.

36. Berzinsh, V. Hydrology. In Ecosystem of the Gulf of Riga between 1920 and 1990; Ojaveer, E., Ed.; Estonian Academy Publishers: Tallinn, Estonia, 1995; pp. 7-32.

37. Skudra, M.; Lips, U. Characteristics and inter-annual changes in temperature, salinity and density distribution in the Gulf of Riga. Oceanologia 2017, 59, 37-48. [CrossRef]

38. Jurgensone, I.; Carstensen, J.; Ikauniece, A.; Kalveka, B. Long-term Changes and Controlling Factors of Phytoplankton Community in the Gulf of Riga (Baltic Sea). Estuar. Coast. 2011, 34, 1205-1219. [CrossRef]

39. HELCOM. Manual for Marine Monitoring in the COMBINE Programme of HELCOM. Available online: https://helcom.fi/ media/publications/Manual-for-Marine-Monitoring-in-the-COMBINE-Programme-of-HELCOM.pdf (accessed on 8 June 2021).

40. Telesh, I.; Heerkloss, R. Atlas of Estuarine Zooplankton of the Southern and Eastern Baltic Sea. Part I: Rotifera; Verlag Dr. Kovač: Hamburg, Germany, 2002; pp. 1-90.

41. Telesh, I.; Heerkloss, R. Atlas of Estuarine Zooplankton of the Southern and Eastern Baltic Sea. Part II: Crustacea; Verlag Dr. Kovač: Hamburg, Germany, 2004; pp. 1-118.

42. ICES ID Leaflets for Plankton. 2021. Available online: https://www.ices.dk/publications/library/Pages/default.aspx\#Default= $\% 7 \mathrm{~B} \% 22 \mathrm{k} \% 22 \% 3 \mathrm{~A} \% 22 \% 22 \% 2 \mathrm{C} \% 22 \mathrm{r} \% 22 \% 3 \mathrm{~A} \% 5 \mathrm{~B} \% 7 \mathrm{~B} \% 22 \mathrm{n} \% 22 \% 3 \mathrm{~A} \% 22$ owstaxIdPublicationType $\% 22 \% 2 \mathrm{C} \% 22 \mathrm{t} \% 22 \% 3 \mathrm{~A} \%$ 5B\%22\%5C\%22\%C7\%82\%C7\%824c307c233061343963306361392d643065372d343661662d393464312d31313638616332346530323 57 c4944204c6561666c657473\%5C $\% 22 \% 22 \% 5 \mathrm{D} \% 2 \mathrm{C} \% 22 \mathrm{o} \% 22 \% 3 \mathrm{~A} \% 22$ and $\% 22 \% 2 \mathrm{C} \% 22 \mathrm{k} \% 22 \% 3 \mathrm{Afalse} \% 2 \mathrm{C} \% 22 \mathrm{~m} \% 22 \% 3 \mathrm{Anull} \%$ 7D $\% 2 \mathrm{C} \% 7 \mathrm{~B} \% 22 \mathrm{n} \% 22 \% 3 \mathrm{~A} \% 22$ ReportAcronymOWSCHCS $\% 22 \% 2 \mathrm{C} \% 22 \mathrm{t} \% 22 \% 3 \mathrm{~A} \% 5 \mathrm{~B} \% 22 \% 5 \mathrm{C} \% 22 \% \mathrm{C7} \% 82 \% \mathrm{C7} \% 8257475 \mathrm{a} 4$ $5 \% 5 \mathrm{C} \% 22 \% 22 \% 5 \mathrm{D} \% 2 \mathrm{C} \% 22 \mathrm{o} \% 22 \% 3 \mathrm{~A} \% 22$ and $\% 22 \% 2 \mathrm{C} \% 22 \mathrm{k} \% 22 \% 3 \mathrm{Afalse} \% 2 \mathrm{C} \% 22 \mathrm{~m} \% 22 \% 3 \mathrm{Anull} \% 7 \mathrm{D} \% 5 \mathrm{D} \% 7 \mathrm{D}$ (accessed on 30 June 2021).

43. ICES. Baltic Fisheries Assessment Working Group (WGBFAS), 6-13 April 2018, ICES HQ, Copenhagen, Denmark. 2018. Available online: https://www.ices.dk/sites/pub/Publication\%20Reports/Expert\%20Group\%20Report/acom/2018/WGBFAS/01\%2 0WGBFAS\%20Report\%202018.pdf (accessed on 8 June 2021).

44. Wilke, T.; Ahlrichs, W.H.; Bininda-Emonds, O.R. Is the valid species Synchaeta monopus Plate, 1889 (Rotifera: Monogononta) a product of preparation artefacts? J. Nat. Hist. 2019, 53, 413-423. [CrossRef]

45. Hébert, M.P.; Beisner, B.E. Functional Trait Approaches for the Study of Metazooplankton Ecology. In Zooplankton Ecology; Teodósio, M.A., Barbosa, A.B., Eds.; CRC Press Taylor \& Francis Group: Boca Raton, FL, USA, 2020; pp. 3-27.

46. Kiørboe, T. How zooplankton feed: Mechanisms, traits and trade-offs. Biol. Rev. 2011, 86, 311-339. [CrossRef] [PubMed] 
47. R Core Team. R: A Language and Environment for Statistical Computing; R Foundation for Statistical Computing: Vienna, Austria, 2019.

48. Hennig, C. fpc: Flexible Procedures for Clustering; R Package Version 2.2-8; 2020. Available online: https://cran.r-project.org/web/ packages/fpc/index.html (accessed on 6 July 2021).

49. Ruttner-Kolisko, A. Plankton Rotifers. Biology and Taxonomy; E.Schweizerbart'sche Verlagsbuchhandlung (Nägele u. Obermiller): Stuttgart, Germany, 1974; pp. 1-146.

50. Berzins, B. Rotatoria (III): Monogonata: Ploima: Brachionidae: Keratella. Available online: https://doi.org/10.17895/ices.pub.50 11 (accessed on 8 June 2021).

51. Pansch, C.; Schlegel, P.; Havenhand, J. Larval development of the barnacle Amphibalanus improvisus responds variably but robustly to near-future ocean acidification. ICES J. Mar. Sci. 2013, 70, 805-811. [CrossRef]

52. Burckhardt, R.; Schumann, R.; Bochert, R. Feeding biology of the pelagic larvae of Marenzelleria cf. viridis (Polychaeta: Spionidae) from the Baltic Sea. Aquat. Ecol. 1997, 31, 149-162.

53. Arapov, J.; Ezgeta-Balić, D.; Peharda, M.; Ninčević Gladan, Ž. Bivalve feeding-How and what they eat? Croat. J. Fish. 2010, $68,105-116$.

54. Raby, D.; Lagadeuc, Y.; Dodson, J.J.; Mingelbier, M. Relationship between feeding and vertical distribution of bivalve larvae in stratified and mixed waters. Mar. Ecol. Prog. Ser. 1994, 103, 275-284. [CrossRef]

55. Sommer, U.; Sommer, F. Cladocerans versus copepods: The cause of contrasting top-down controls on freshwater and marine phytoplankton. Oecologia 2006, 147, 183-194. [CrossRef]

56. Hansen, B.; Bjornsen, P.K.; Hansen, P.J. The size ratio between planktonic predators and their prey. Limnol. Oceanogr. 1994, 39, 395-403. [CrossRef]

57. Brun, P.; Payne, M.R.; Kiørboe, T. A trait database for marine copepods. Earth Syst. Scit. Data 2017, 9, 99-113. [CrossRef]

58. García, C.E.; Nandini, S.; Sarma, S. Demographic characteristics of the copepod Acanthocyclops americanus (Sars, 1863) (Copepoda: Cyclopoida) fed mixed algal (Scenedesmus acutus)-rotifer (Brachionus havanaensis) diet. Hydrobiologia 2011, 666, 59-69. [CrossRef]

59. Egloff, D.A.; Fofonoff, P.W.; Onbé, T. Reproductive biology of marine cladocerans. Adv. Mar. Biol. 1997, 31, 79-167.

60. Katechakis, A.; Stibor, H. Feeding selectivities of the marine cladocerans Penilia avirostris, Podon intermedius and Evadne nordmanni. Mar. Biol. 2004, 145, 529-539. [CrossRef]

61. Tiselius, P. Contribution of aloricate ciliates to the diet of Acartia clausi and Centropages hamatus in coastal waters. Mar. Ecol. Prog. Ser. 1989, 56, 49-56. [CrossRef]

62. Gentsch, E.; Kreibich, T.; Hagen, W.; Niehoff, B. Dietary shifts in the copepod Temora longicornis during spring: Evidence from stable isotope signatures, fatty acid biomarkers and feeding experiments. J. Plankton Res. 2009, 31, 45-60. [CrossRef]

63. Hollowday, E. Family Synchaetidae Hudson \& Gosse, 1886. In Guides to the Identification of the Microinvertebrates. ROTIFERA; Nograndy, T., Segers, H., Eds.; Backhuys Publishers: Leiden, The Netherlands, 2002; Volume 6, pp. 87-264.

64. Titelman, J.; Kiørboe, T. Motility of copepod nauplii and implications for food encounter. Mar. Ecol. Prog. Ser. 2003, 247, 123-135. [CrossRef]

65. Stoecker, D.K.; Egloff, D.A. Predation by Acartia tonsa Dana on planktonic ciliates and rotifers. J. Exp. Mar. Biol. Ecol. 1987, 110, 53-68. [CrossRef]

66. Warren, G.J. Predaceous feeding habits of Limnocalanus macrurus. J. Plankton Res. 1985, 7, 537-552. [CrossRef]

67. Rivier, I.K. The predatory Cladocera (Onychopoda: Podonidae, Polyphemidae, Cercopagidae) and Leptodorida of the World. In Guides to the Identification of the Micro-Invertebrates of the Continental Waters of the World; Dumont, H., Ed.; SPB Academic Pub: The Hague, The Netherlands, 1998; pp. 1-213.

68. Aladin, N.V.; Panov, V.E. Comparative biology of the predatory cladoceran Cercopagis pengoi from Lake Ontario, Baltic Sea and Caspian Sea. Arch. Hydrobiol. 2000, 1, 23-50.

69. Revis, N.; Castel, J.; Tackx, M. Some reflections on the structure of the mandibleplate of Eurytemora affinis (Copepoda, Calanoida). Hydrobiol. Bull. 1991, 25, 45-50. [CrossRef]

70. Laliberté, E.; Legendre, P. A distance-based framework for measuring functional diversity from multiple traits. Ecology 2010, 91, 299-305. [CrossRef]

71. Laliberté, E.; Legendre, P.; Shipley, B. FD: Measuring Functional Diversity from Multiple Traits, and Other Tools for Functional Ecology; R Package Version 1.0-12; 2014. Available online: https:/ /rdrr.io/cran/FD/ (accessed on 6 July 2021).

72. Mason, N.; Mouillot, D.; Lee, W.; Wilson, J. Functional richness, functional evenness and functional divergence: The primary components of functional diversity. Oikos 2005, 1, 112-118. [CrossRef]

73. Rao, C.R. Diversity and dissimilarity coefficients: A unified approach. Theor. Popul. Biol. 1982, 21, 24-43. [CrossRef]

74. Swenson, N.G. Functional and Phylogenetic Ecology in R; Springer: New York, NY, USA, 2014; pp. 1-209.

75. Kembel, S.; Cowan, P.; Helmus, M.; Cornwell, W.; Morlon, H.; Ackerly, D.; Blomberg, S.; Webb, C. Picante: R tools for integrating phylogenies and ecology. Bioinformatics 2010, 26, 1463-1464. [CrossRef] [PubMed]

76. Lê, S.; Josse, J.; Husson, F. FactoMineR: A Package for Multivariate Analysis. J. Stat. Softw. 2008, 25, 1-18. [CrossRef]

77. Peterson, R.A.; Cavanaugh, J.E. Ordered quantile normalization: A semiparametric transformation built for the cross-validation era. J. Appl. Stat. 2020, 47, 2312-2327. [CrossRef]

78. Otto, S.A.; Plonus, R.; Funk, S.; Keth, A. INDperform: Evaluation of Indicator Performances for Assessing Ecosystem States; R Package Version 0.2.2.9000; 2020. Available online: https:/ /rdrr.io/cran/INDperform/ (accessed on 6 July 2021). 
79. Gasiūnaitè, Z.R. Coupling of the limnetic and brackishwater plankton crustaceans in the Curonian Lagoon (Baltic Sea). Int. Rev. Hydrobiol. 2000, 85, 653-661. [CrossRef]

80. Telesh, I.V. Plankton of the Baltic estuarine ecosystems with emphasis on Neva Estuary: A review of present knowledge and research perspectives. Mar. Pollut. Bull. 2004, 49, 206-219. [CrossRef]

81. Connell, J.H. Diversity in tropical rain forests and coral reefs. Science 1978, 199, 1302-1310. [CrossRef]

82. Wilkinson, D.M. The disturbing history of intermediate disturbance. Oikos 1999, 84, 145-147. [CrossRef]

83. Lips, U.; Zhurbas, V.; Skudra, M.; Väli, G. A numerical study of circulation in the Gulf of Riga, Baltic Sea. Part I: Whole-basin gyres and mean currents. Cont. Shelf Res. 2016, 112, 1-13. [CrossRef]

84. Forster, J.; Hirst, A.G. The temperature-size rule emerges from ontogenetic differences between growth and development rates. Funct. Ecol. 2012, 26, 483-492. [CrossRef]

85. Kenitz, K.M.; Visser, A.W.; Mariani, P.; Andersen, K.H. Seasonal succession in zooplankton feeding traits reveals trophic trait coupling. Limnol. Oceanogr. 2017, 62, 1184-1197. [CrossRef]

86. Kiørboe, T.; Visser, A.; Andersen, K.H. A trait-based approach to ocean ecology. ICES J. Mar. Sci. 2018, 75, 1849-1863. [CrossRef]

87. McManus, M.A.; Woodson, C.B. Plankton distribution and ocean dispersal. J. Exp. Biol. 2012, 215, 1008-1016. [CrossRef] [PubMed]

88. Kahru, M.; Nômmann, S.; Simm, M.; Vilbaste, K. Plankton Distributions and Processes in the Baltic Boundary Zones. In Marine Interfaces Ecohydrodynamics; Nihoul, J., Ed.; Elsevier: Oxford, UK, 1986; pp. 273-294.

89. Winder, M.; Varpe, Ø. Interactions in Plankton Food Webs: Seasonal Succession and Phenology of Baltic Sea Zooplankton. In Zooplankton Ecology; Teodósio, M.A., Barbosa, A.B., Eds.; CRC Press Taylor \& Francis Group: Boca Raton, FL, USA, 2020; pp. 162-191.

90. Viitasalo, M.; Katajisto, T. Mesozooplankton resting eggs in the Baltic Sea: Identification and vertical distribution in laminated and mixed sediments. Mar. Biol. 1994, 120, 455-466. [CrossRef]

91. Carman, R.; Aigars, J.; Larsen, B. Carbon and nutrient geochemistry of the surface sediments of the Gulf of Riga, Baltic Sea. Mar. Geol. 1996, 134, 57-76. [CrossRef]

92. Paerl, H.W.; Otten, T.G. Harmful cyanobacterial blooms: Causes, consequences, and controls. Microb. Ecol. 2013, 65, 995-1010. [CrossRef]

93. Tillmanns, A.R.; Wilson, A.E.; Pick, F.R.; Sarnelle, O. Meta-analysis of cyanobacterial effects on zooplankton population growth rate: Species-specific responses. Fund. Appl. Limnol. 2008, 171, 285-295. [CrossRef]

94. Finkel, Z.V.; Beardall, J.; Flynn, K.J.; Quigg, A.; Rees, T.A.V.; Raven, J.a. Phytoplankton in a changing world: Cell size and elemental stoichiometry. J. Plankton Res. 2010, 32, 119-137. [CrossRef]

95. Jónasdóttir, S. Fatty Acid Profiles and Production in Marine Phytoplankton. Mar. Drugs 2019, 17, 151. [CrossRef] [PubMed]

96. Wejnerowski, L.; Cerbin, S.; Dziuba, M.K. Thicker filaments of Aphanizomenon gracile are more harmful to Daphnia than thinner Cylindrospermopsis raciborskii. Zool. Stud. 2015, 54, 2. [CrossRef] [PubMed]

97. Gorokhova, E.; El-Shehawy, R.; Lehtiniemi, M.; Garbaras, A. How Copepods Can Eat Toxins Without Getting Sick: Gut Bacteria Help Zooplankton to Feed in Cyanobacteria Blooms. Front. Microbiol. 2021, 11, 589816. [CrossRef]

98. Krztoń, W.; Kosiba, J.; Pociecha, A.; Wilk-Woźniak, E. The effect of cyanobacterial blooms on bio- and functional diversity of zooplankton communities. Biodivers Conserv. 2019, 28, 1815-1835. [CrossRef]

99. Landry, M.R.; Calbet, A. Microzooplankton production in the oceans. ICES J. Mar. Sci. 2004, 61, 501-507. [CrossRef]

100. Möllmann, C.; Diekmann, R.; Müller-Karulis, B.; Kornilovs, G.; Plikshs, M.; Axe, P. Reorganization of a large marine ecosystem due to atmospheric and anthropogenic pressure: A discontinuous regime shift in the Central Baltic Sea. Glob. Chang. Biol. 2009, 15, 1377-1393. [CrossRef]

101. Kortsch, S.; Frelat, R.; Pecuchet, L.; Olivier, P.; Putnis, I.; Bonsdorff, E.; Ojaveer, H.; Jurgensone, I.; Strāke, S.; Rubene, G.; et al. Disentangling temporal food web dynamics facilitates understanding of ecosystem functioning. J. Anim. Ecol. 2021, 90, 1205-1216. [CrossRef]

102. Ojaveer, H.; Kotta, J.; Põllumäe, A.; Põllupüü, M.; Jaanus, A.; Vetemaa, M. Alien species in a brackish water temperate ecosystem: Annual-scale dynamics in response to environmental variability. Environ. Res. 2011, 111, 933-942. [CrossRef]

103. Ojaveer, H.; Simm, M.; Lankov, A. Population dynamics and ecological impact of the non-indigenous Cercopagis pengoi in the Gulf of Riga (Baltic Sea). Hydrobiologia 2004, 522, 261-269. [CrossRef]

104. Gorokhova, E.; Fagerberg, T.; Hansson, S. Predation by herring (Clupea harengus) and sprat (Sprattus sprattus) on Cercopagis pengoi in a western Baltic Sea bay. ICES J. Mar. Sci. 2004, 61, 959-965. [CrossRef]

105. Gorokhova, E.; Hansson, S.; Höglander, H.; Andersen, C.M. Stable isotopes show food web changes after invasion by the predatory cladoceran Cercopagis pengoi in a Baltic Sea bay. Oecologia 2005, 143, 251-259. [CrossRef] [PubMed]

106. Ojaveer, E. Ecosystems and Living Resources of the Baltic Sea: Their Assessment and Management; Springer: Cham, Switzerland, 2017; pp. $1-283$.

107. Arula, T.; Kotta, J.; Lankov, A.; Simm, M.; Põlme, S. Diet composition and feeding activity of larval spring-spawning herring: Importance of environmental variability. J. Sea Res. 2012, 68, 33-40. [CrossRef]

108. Arrhenius, F.; Hansson, S. Food consumption of larval, young and adult herring and sprat in the Baltic Sea. Mar. Ecol. Prog. Ser. 1993, 96, 125. [CrossRef] 